\title{
Ammonia synthesis catalyst 100 years: Practice, enlightenment and challenge
}

\author{
Huazhang Liu* \\ Institute of Industrial Catalysis of Zhejiang University of Technology, Hangzhou 310014, Zhejiang, China
}

\section{A R T I C L E I N F O}

\section{Article history:}

Received 19 March 2014

Accepted 23 April 2014

Published 20 October 2014

\section{Keywords:}

Ammonia synthesis catalyst

Discovery

Development

Challenge

Practice

Enlightenment
A B S T R A C T
Ammonia synthesis catalyst found by Haber-Bosch achieves its history of 100 years. The current understanding and enlightenment from foundation and development of ammonia synthesis catalyst are reviewed, and its future and facing new challenge remained today are expected. Catalytic ammonia synthesis technology has played a central role in the development of the chemical industry during the 20th century. During 100 years, ammonia synthesis catalyst has come through diversified seedtime such as $\mathrm{Fe}_{3} \mathrm{O}_{4}$-based iron catalysts, $\mathrm{Fe}_{1-\mathrm{x}} \mathrm{O}$-based iron catalysts, ruthenium-based catalysts, and discovery of a Co-Mo-N system. Often new techniques, methods, and theories of catalysis have initially been developed and applied in connection with studies of this system. Similarly, new discoveries in the field of ammonia synthesis have been extended to other fields of catalysis. There is no other practically relevant reaction that leads to such a close interconnection between theory, model catalysis, and experiment as the high-pressure synthesis of ammonia. Catalytic synthesis ammonia reaction is yet a perfect model system for academic research in the field of heterogeneous catalysis. Understanding the mechanism and the translation of the knowledge into technical perfection has become a fundamental criterion for scientific development in catalysis research. The never-ending story has not ended yet. In addition to questions about the elementary steps of the reaction and the importance of the real structure and subnitrides for the catalyst efficiency, as well as the wide-open question about new catalyst materials, there are also different challenges thrown down by theory for the experimentalist in the prediction of a biomimetic ammonia-synthesis path at room temperature and atmospheric pressure including electrocatalysis, photocatalysis and biomimetic nitrogen fixation.

(C) 2014, Dalian Institute of Chemical Physics, Chinese Academy of Sciences. Published by Elsevier B.V. All rights reserved.

\section{The invention and enlightenment of ammonia synthesis catalyst}

The ammonia synthesis industry has developed rapidly since the first ammonia synthesis device over the world started to produce ammonia in September 9th, 1913. To early 2000s, the ammonia synthesis devices with daily production capability of 1000 or $2200 \mathrm{t}$ are worldwide. Ammonia synthesis has been a pillar of chemical industry and a milestone in the history of conquest of nature made by human beings.
In the process of this great invention, unprecedented difficulties have been encountered [1]. In 1787, C. L. Berthollet proposed that ammonia consisted of elemental nitrogen and hydrogen. Many distinguished chemists at that time, including W. H. Nernst, W. Ostward, F. Haber, etc., immediately contributed great efforts into research about ammonia synthesis by elemental nitrogen and hydrogen. However, the first obstacle they faced was chemical equilibrium. The law of mass action and the law of chemical equilibrium did not be found at that time, so that concentration of ammonia in the equilibrium was 
unclear. At atmospheric pressure, ammonia was only generated at very low temperature, but it decomposed at high temperature. Therefore, many scientists even believed that the generation of ammonia by the elemental hydrogen and nitrogen was an insurmountable obstacle.

At that critical moment, Haber first proposed to use high pressure reaction technique. However, it was still hard to realize industrial scale production due to low conversion-per-pass of ammonia. So Haber abandoned the popular static view and adopts a dynamic method by introducing an important concept, the reaction rate, which using space-time yield to replace reaction yield. Based on this important principle, he developed closed process flow and loop operation technology. These three technologies and concept of reaction rate were a great invention that provided the basis for the construction of experimental apparatus to produce ammonia and achieved the first pressurized catalytic process in industrial history. This was a milestone in the development history of the catalytic process that represented the beginning of a new era of industrial catalysis. Only a few years later, methanol synthesis, Fischer-Tropsch synthesis and high-pressure reaction technology in the presence of heterogeneous catalysts that appeared subsequently have become essential practices in the field of organic chemistry, and promoted the entire chemical and material industries. Haber's unprecedented creations established the basis for the entire chemical engineering science.

In February 1908, Haber signed an agreement with Baden Aniline and Soda Company (BASF). BASF assigned the task of industrial development to Carl Bosch. Bosch immediately was aware enough of the fact that he had to address three major challenges: designing methods to produce low-cost hydrogen and nitrogen; exploring an efficient and stable catalyst; developing equipment and materials for high-pressure ammonia synthesis.

Haber and other scientists energetically explored catalysts. Haber discovered that osmium and uranium-uranium carbide catalysts displayed excellent performance on ammonia synthesis. BASF Corporation acquired purchase rights for osmium in stock all over the world, a total of about $100 \mathrm{~kg}$. Although it sounds incredible today, it did fully reflect the passion of scientists and entrepreneurs at that time. However, Haber was appointed the director of the Institute of Physical Chemistry and

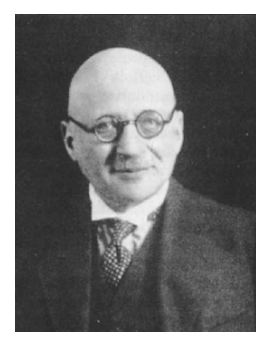

Fritz Haber (1868-1934)

Laid the theoretical basis on synthesis of ammonia, awarded the 1919 Nobel Prize in Chemistry.

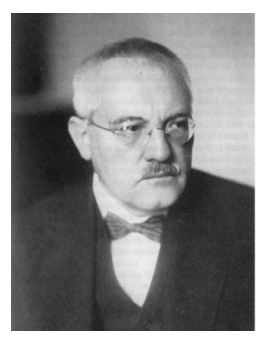

Carl Bosch (1874-1940) Realized the industrial synthesis of ammonia, awarded the 1931 Nobel Prize in Chemistry.

Electrochemistry Kaiser Wilhelm Institute in 1912, which also marked the end of Haber's research activities in the field of ammonia synthesis.

Bosch assigned the task on finding efficient and stable catalysts to his assistant Alwin Mittasch. Mittasch first conducted extensive studies on metal nitrides in an attempt to fix the nitrogen in air by the indirect route. Although that technique was unsuccessful for the ammonia synthesis, it provided valuable information on the catalytic properties of almost all the metal elements in periodic table. He recognized that many of metals itself presented only little or no catalytic effect, but an additive could improve their catalytic activity. Based on these findings, in February 1909 he made an unproven hypothesis: "the winning catalyst should be a multi-components system" and it needed a very large number of tests to determine. For this reason, BASF produced a variety of model reactors for catalyst tests. From 1909 to 1911, in about a year and a half, 2500 of different catalysts were tested at 6500 times. That amazing catalyst selection trial, continued until 1922 before it was over, with a total of 20000 times of testing for over 5000 different catalyst systems.

Iron has been known as an effective catalyst for ammonia synthesis since the year of 1905 . However, it was proved to be disappointing in BASF's initial experiments. Someday Mittasch's assistant Wolf inadvertently used Swedish-produced Gallivare iron ore samples which had been placed on the shelf of the laboratory a few years to test the synthesis of ammonia, and received unexpected results. He found that if a few percent of alumina, a small amount of calcium oxide and potassium alkali were fused into pure iron, a suitable catalyst for the synthesis of ammonia was obtained. The best catalyst was proved to be a multi-component mixture, which comprised the similar composition of Gallivare magnetite. That is the magnetite-based fused iron catalyst with a small amount of promoter which is still used today. The mixed catalyst is proved to be so effective that even now all ammonia catalysts in the world are still manufactured based on this principle.

Haber, Bosch, Mittasch, and Ertl these four great scientists have made a great contribution on the creation and development of ammonia synthetic industry, among whom Haber, Bosch, and Ertl were awarded the Nobel Prize in Chemistry.

The successful development of synthetic ammonia industry

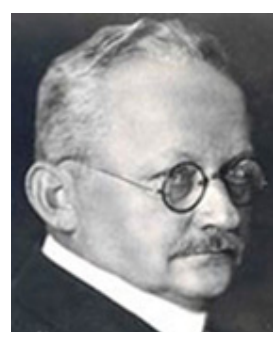

Alwin Mittasch (1869-1953) The major developer for fused iron catalyst, who proposed the concept of mixed catalyst.

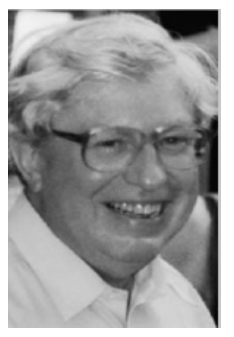

Gerhard Ertl (1936-)

Great contribution on iron catalyst surface chemistry research, awarded the 2007 Nobel Prize in Chemistry. 
is not only a great technical achievement but also a masterpiece of the organization work, which become a precedent in early stage for today's prevalent collaborative innovation (team work). In the creation process, Haber, Bosch and Mittasc's the great creation, brilliant scientific ideas and innovative spirit, the passion and spirit of cooperation from scientists and entrepreneurs, as well as the team spirit of cooperation and collaborative innovation among chemists, engineers, physicists, materials scientists and a variety of artisans group, are worthy of our admiration and learning.

Great success on ammonia industry has changed the history of world food production. According to the statistics from UN Food and Agriculture Organization (FAO), fertilizer contributes more than $40 \%$ to food production. Thus, the catalytic ammonia synthesis technology invented by Haber and Bosch is considered to be one of the greatest contributions to human beings. From the technological invention to the present, the Earth's population has grown by 4.2 times from 1.7 billion at the beginning of the 20th century, while food production has increased by 7.8 times. Humans can still produce ample food and clothing under the limited land resources, mainly rely on such technology created by Haber and Bosch. Now, $50 \%$ of nitrogen in our body is from ammonia synthesis [2], which mean, if without such invention, $50 \%$ of people in the Earth cannot survive. China is also unlikely to feed 20 percent of the world's population by only $7 \%$ of arable land all over the world.

After a century of development, catalytic synthesis of ammonia has made tremendous progress. The production capacity of single set equipment has been improved from the original $5 \mathrm{t}$ of daily ammonia production to the current $2200 \mathrm{t}$. The reaction pressure has dropped to $10-15 \mathrm{MPa}$ from the original $100 \mathrm{MPa}$. The energy consumption has decreased to $27.2 \mathrm{GJ}$ from the original $78 \mathrm{GJ}$, which is close to the theoretical energy consumption of $20.1 \mathrm{GJ}$. But as the second largest chemicals, the ammonia production still consumes $2 \%$ of total energy supply in the world and releases more than $400 \mathrm{Mt}$ of $\mathrm{CO}_{2}$, which accounts for $1.6 \%$ of total global $\mathrm{CO}_{2}$ emissions.

\section{The development and enlightenment of ammonia synthesis catalysts}

The invention of fused iron catalyst creates a catalytic ammonia synthesis industry. Iron catalysts for ammonia synthesis become one of the most successful and studied thorough catalysts in the world. With the development of petrochemical, coal chemical, bio-chemical, polymer, materials, energy and environment, the relative position of research on ammonia synthesis catalyst in the catalytic domain gradually declines, and it is no longer the main aspects of catalysis research, but the rigid demand for food decides the irreplaceable traditional ammonia industry can only rely on technological progress to constantly evolve. The catalyst of any progress can improve thermodynamic efficiency and lower product prices. Therefore, advances of ammonia industry and its catalyst technology will not stop. Initially, the suitable Fe catalyst was only found by F. Haber from about 5000 tried catalysts; currently, in order to further improve the process and reduce energy consumption, further improving the catalyst is still the only hope.

\subsection{Development of ammonia synthesis catalyst}

Currently fused iron catalysts still occupy the absolute position in industry with tens of catalyst product types, of which more than ten kinds are developed by Chinese. Nanjing Chemical Industry Company developed the A102 ammonia synthesis catalyst in 1951, which was the first Chinese self-developed ammonia synthesis catalyst, and followed by successful development of type A106 and A109 ammonia synthesis catalysts. In 1979, Zhejiang University of Technology successfully developed type A110-2 low temperature ammonia synthesis catalyst [3]. After that the Nanjing Chemical Industry Research Institute, Fuzhou University, Lin Qu Catalyst Plant, Zhengzhou University, Hubei Institute of Chemistry, etc. successfully developed type A110-1, A110- 3, A110-4, A110-5Q (spherical) and A110-6 catalysts, which formed a widely applied A110 catalysts family since 1980s [4].

Co-containing catalyst is an important development for the traditional $\mathrm{Fe}_{3} \mathrm{O}_{4}$-based fused iron catalyst. The British company ICI applied patents on cobalt-containing catalyst in 1978, and successfully developed 74-1 type cobalt-containing catalyst in 1979. In 1985, Fuzhou University successfully developed A201 type cobalt catalyst [5], then the amount of cobalt in A201 was further reduced and $\mathrm{CeO}_{2}$ was added, which was called as the type A202 cobalt-containing catalyst in 1995 [6]. In addition, South China University of Technology, Nanjing Chemical Company, Zhengzhou University, also developed their cobalt-containing catalysts $[4,7]$.

Since ruthenium-based catalyst for ammonia synthesis is invented in the 1990s, most of scientists have shifted their main research directions and attention to the study of ruthenium-based catalyst, and thus fused iron catalyst research has become less popular. Only a few of universities and research institutions around the world are still studying fused iron catalysts, such as Szczecin University of Technology in Poland [8-10], Fuzhou University [11] and Zhejiang University of Technology [12]. Others such as the Fritz Haber Institute Max-Planck-Society in Germany [13] occasionally published research papers on iron catalysts for ammonia synthesis.

To 1970s, the fused iron catalyst was considered well consolidated and no special improvement was still expected. The industrial iron catalyst presently used is not basically different from that developed 100 years ago [14]. It has become more difficult to achieve significant progress. This will encourage people to seek a major technological breakthrough-one kind of jumping or discontinuous technological progress. Nearly 30 years, the discoveries of Fe1-xO-based catalyst system, ruthenium-based catalyst and cobalt and molybdenum bimetallic nitride catalyst are expressing the idea of seeking technical breakthroughs (Table 1).

\subsubsection{The discovery of $\mathrm{Fe}_{1-\mathrm{x}} \mathrm{O}$-based ammonia synthesis catalyst}

In the past century, scholars always believed that when the precursor of fused iron catalysts was $\mathrm{Fe}_{3} \mathrm{O}_{4}$, catalysts showed the highest activity. Therefore, people confined their thinking 
Table 1

Development of ammonia synthesis catalysts.

\begin{tabular}{|c|c|c|c|c|}
\hline Development stage & Year & Inventor & Catalyst type & Chemical composition \\
\hline (1) $\mathrm{Fe}_{3} \mathrm{O}_{4}$-based catalyst & 1913 & BASF, Germany & S6-10, KM & $\mathrm{Fe}_{3} \mathrm{O}_{4}+\mathrm{Al}_{2} \mathrm{O}_{3}+\mathrm{K}_{2} \mathrm{O}+\mathrm{CaO}+\ldots$ \\
\hline (2) $\mathrm{Fe}_{1-x} \mathrm{O}$-based catalyst & 1986 & Zhejiang Univ. of Technol., China & A301, ZA-5 & $\mathrm{Fe}_{1-x} \mathrm{O}+\mathrm{Al}_{2} \mathrm{O}_{3}+\mathrm{K}_{2} \mathrm{O}+\mathrm{CaO}+\ldots$ \\
\hline (3) Ru-based catalyst & 1992 & UK-BP, Japan & KAAP & $\mathrm{Ru}-\mathrm{Ba}-\mathrm{K} / \mathrm{AC}$ \\
\hline
\end{tabular}

on $\mathrm{Fe}_{3} \mathrm{O}_{4}$ catalyst in the past fused iron catalyst research and development, and improved the catalyst activity and life just by changing the type and number of promoter, while ignoring the impact of catalyst precursor phase. Although research and improvement had been doing by scientists in countries, magnetite was still of the dominance [15]. In 1986 Zhejiang University of Technology[16-21] invented $\mathrm{Fe}_{1-x} \mathrm{O}$-based catalyst with Wustite structure, which broke the shackle of the traditional conclusion "the fused iron catalyst with $\mathrm{Fe}_{3} \mathrm{O}_{4}$ as precursor shows the highest activity", and found a breakthrough in improving the performance of fused iron catalyst-Wustite catalyst system. It marked 80 years of research on fused iron catalysts had been made a substantial progress which kept the development of fused iron catalyst alive. $\mathrm{Fe}_{1-\mathrm{x}} \mathrm{O}$-based ammonia synthesis catalyst is most active fused iron catalyst in the world. This discovery causes widespread concern and interest in domestic and foreign scholars $[13,14,22,23]$, and has been widely used in industry.

The author [24] has the opportunity to witness the construction and development of China's ammonia industry from the 1960s, and devotes his life to the development of catalytic ammonia technology. He contributes his effort on the various research stages of the catalyst which start from $\mathrm{Fe}_{3} \mathrm{O}_{4}$-based, cobalt-containing $\mathrm{Fe}_{3} \mathrm{O}_{4}$-based, $\mathrm{Fe}_{1-\mathrm{x}} \mathrm{O}$-based to ruthenium-based catalysts. He created the $\mathrm{Fe}_{1-x} \mathrm{O}$-based catalyst and its theory system based on the monophase principle of iron oxides, and collaborated with his colleagues to successfully develop new industrial catalysts of type A110-2, A301, ZA-5, etc., which have become one of major industrial ammonia synthesis catalysts in nearly 30 years.

\subsubsection{The discovery of ruthenium-based catalysts for ammonia synthesis}

The $\mathrm{Fe}_{3} \mathrm{O}_{4}$-based iron catalyst was considered well consolidated and no special improvement was still expected. Scientists abroad started to look for non-ferrous noble metal catalysts. 40 years ago, Ozaki et al. [25] in a review article proposed that chemical adsorption of nitrogen and catalytic efficiency of elements in ammonia synthesis and decomposition could be associated, and thus could obtain a volcano-shaped curve to quantitatively descript the catalytic efficiency of metal elements in ammonia synthesis. In this graph, ruthenium, osmium, and iron are at the top of the volcano-shaped curve. Under industrial conditions, the use of Ru and Os catalysts has been close to the optimum point. Both theoretical and practical studies in nearly a hundred years have shown that $\mathrm{Ru}$, Os and Fe are the best pure metal catalysts.

The development of ruthenium catalyst has a long history [26]. The first report about the application of ruthenium catalyst in synthesis of ammonia was published in 1917, in which
Mittasch, etc. believed that catalytic activity of ruthenium catalysts in the ammonia process is not as good as that of iron catalyst. Then ruthenium catalyst had not been reported in a long time period. In 1969, Tamaru [27] proposed a transition metal electron donor-acceptor type (EDA) of ammonia synthesis catalyst system. In this catalyst system, they chose the alkali metal potassium or sodium as electron donors, transition metals such as iron, ruthenium, osmium, cobalt, etc. as electron acceptors and staff with electrons transport capability such as phthalocyanine, polyphenylene quinone, graphite or graphitized carbon as carriers, and it showed high catalytic activity in ammonia synthesis under mild conditions. In 1972, Ozaki et al [28] found that when ruthenium as an active component, potassium as a metal promoter, carbon as a catalyst carrier, the catalyst system showed high activity for ammonia synthesis. That discovery once again sparked scientists' interest in studying ruthenium catalysts. After that, researchers in Japan, Russia, UK, USA, Italy and other countries, as well as Zhejiang University of Technology, Fuzhou University, Xiamen University, Dalian Institute of Chemical Physics (DICP) and other units in our country [29-32] put a large amount of energy into the development of ruthenium catalysts in order to replace traditional iron-based catalysts. British Petroleum (BP) was responsible for loading ruthenium carbonyl compounds on graphite carbon carriers to be a new $\mathrm{Ru} / \mathrm{C}$ catalyst. Kellogg was responsible for developing the ammonia synthesis process by using that $\mathrm{Ru} / \mathrm{C}$ catalyst. With 10 years of joint efforts, they successfully developed in 1992 a new ammonia synthesis process KAAP (Kellogg Advanced Ammonia Process) which was applicable to $\mathrm{Ru} / \mathrm{C}$ catalyst, and achieved its industrial applications [33-35].

Although ruthenium catalysts are highly active, their strong inhibition of $\mathrm{H}_{2}$ and the methanation of carbon material of the carriers in Ru catalyst under conditions of ammonia synthesis which results in loss of active carbon carrier and shortening the life of catalyst, are weaknesses of the ruthenium catalysts. Meanwhile, the $\mathrm{Ru}$ and Os are very expensive, which is lack of commercial appealing compared to the third-best Fe catalyst [36]. Os and $U$ are abandoned by Haber in the early 20th century. $\mathrm{Ru} / \mathrm{C}$ catalyst is not much advantage in energy efficiency (Table 2). From 1992 to 2010, only 16 ammonia plants used ruthenium catalysts. Therefore, it can be said that theoretical meaning of ruthenium catalysts is larger than its practical meaning. The industry is still necessary to find more efficient and cheaper catalysts than ruthenium catalysts.

\subsubsection{The discovery of Co-Mo nitride catalyst for ammonia synthesis}

Nörskov et al [36] proposed an alloy catalyst is designed by interpolation in the periodic table. This catalyst development strategy was obtained by simple physical principles, so its basic 
Table 2

Comparison of iron catalysts and ruthenium catalysts.

\begin{tabular}{lccccc}
\hline \multirow{2}{*}{ Catalyst type } & \multirow{2}{*}{ Resource } & Manufacturing cost & \multicolumn{2}{c}{ Conditions } & Energy consumption \\
\cline { 3 - 6 } & & $\left(10^{3 *}\right.$ Yuan $\left./ \mathrm{m}^{3}\right)$ & $T /{ }^{\circ} \mathrm{C}$ & $P / \mathrm{MPa}$ & $\mathrm{H}_{2} / \mathrm{N}_{2}$ \\
\hline $\mathrm{Fe}$ & abundant & 30 & $350-525($ wide) & $10-30$ & $2-3$ \\
$\mathrm{Ru} / \mathrm{AC}$ & scarce & 1600 & $325-450$ (narrow) & $\leq 10$ & $\sim 27$ \\
\hline
\end{tabular}

principle could be widely applied. According to this principle, a reasonable assumption was that the elements which reacted with nitrogen very actively and very inactively in A. Ozaki volcano-shaped curve together form alloy to construct a new active surface in order to achieve the most optimal performance. The result showed that the activity of cobalt-molybdenum nitride catalyst was higher than that of $\mathrm{Ru}$ and Os catalysts; was also better than the activity of either single component for ammonia synthesis; was even better than $\mathrm{Fe}$ and $\mathrm{Ru}$ at low $\mathrm{NH}_{3}$ concentration [37-41]. The discovery of cobalt-molybdenum nitride catalyst is considered to be the latest vertex so far in the study of ammonia synthesis catalyst according to theoretical predictions $[42,43]$.

The experiments of Ertl [44] and Somorjai [45] can improve understanding on ammonia synthesis and allow quantitative theoretical description and prediction on the reaction. First, on the basis of basic knowledge on reaction pathways and transition state theory, the quantitative description of catalytic efficiency of the elements in the ammonia synthesis can be obtained. It thus can predict the catalytic efficiency of alloy systems $[36,46]$. Research results on the Co-Mo-N system $[36,47]$ confirm that the both theory and experience in the choice of catalyst are equally useful. This impressive success stories show that according to the target reaction process, a new catalyst system can be designed base on pure theory $[36,48]$. Thus, the discovery of non-ferrous and alloy catalysts will once again promote the development of heterogeneous catalysis science.

Herein, that we need to concern is what the research methods of discovery and development of catalyst for ammonia synthesis can give inspiration to us. During the invention of ammonia synthesis catalyst, Mittasch, etc. used test screening method which relied on a large number of experiments and was a completely novel approach at that time. That method is so effective that people are still following it. The discovery of cobalt molybdenum nitride catalyst provide us with another new research method, which means that catalyst can be designed by pure theory, including the interpolation in the periodic table to design catalysts. With understanding the theoretical knowledge and regularities of catalytic science in depth, as well as accumulation of a lot of information and experience, especially with the development of computer technology, design of catalyst based on the theory and in the "molecular" level changes to be possible. In recent years, a variety of expert systems to assist the design of catalysts have developed [49-52].

\subsection{Peculiarity of fused Fe catalyst and inspirations from its theory and practice}

The catalytic chemistry in ammonia synthesis has special charm. so that attracts the attention and interest from many chemists., Many famous physical chemist and catalytic scientists at the present age, such as W.H. Nernst, W. Ostward, F. Haber, C. Bosch, M.I. Temkin, G. Ertl, P. Emmett, A. Nielsen, H. Topsøe, G.A. Samorjai, J.A. Dumesic, J.K. Norskov, M. Boudart, etc. have been attended or involved in research of catalytic ammonia synthesis [53-58], and published a number of monographs [24,59-62]. This is because the fused iron catalysts have some special properties.

(1) In the development of the chemical industry in the 20th century, the catalytic ammonia technology played a critical role [63]. The importance of this industry associated with that people's strong interest on understanding of important scientific value and technological progress on the ammonia synthesis catalyst. Typically, the development of new technologies, new methods and new theory which were relative to catalysis usually started from this reaction system, or were first applied to this reaction system. Similarly, new discoveries in the field of catalytic synthesis of ammonia were often extended to other catalytic fields. The development of fine characterization techniques, dynamic analysis and new theoretical models have greatly promoted to the in-depth understanding of the foundation of ammonia synthesis catalysts.

Even being constantly improved for centuries, the nature of fused iron catalyst still unchanged. To date, all studies on the synthesis of ammonia have been based on this catalyst. For example, the completion of well-known BET adsorption theory on the iron catalyst; method for determining the active component of the catalyst surface by selective chemical adsorption invented by P. Emmett; the work based on nitrogen selective adsorption on $\mathrm{Fe}(111)$ crystal face laid the foundation of metal cluster catalysis theory which gradually formed in the 1980s; the important assumption of "crystal surface with the largest ligand number shows the greatest catalytic activity" and the concept of structure-sensitive reactions proposed by G. A. Somorjai; the concept of stoichiometric number was proposed by J. Horiuti to verify the kinetics mechanism of ammonia synthesis reaction; M.I. Temkin theory and his famous ammonia synthesis kinetic equation, was the first successfully employed and is now still being used in design of industrial reactors, and also laid the foundation for heterogeneous catalytic reaction kinetics. These theories and concepts, led the development of a series of basic theory, laid the foundation for heterogeneous catalysis science. History of ammonia synthesis reaction and the catalyst is a microcosm of the history of heterogeneous catalysis.

Temkin's theory of catalytic reaction kinetics on non-uniform surface not only has been proven by data of overall reaction kinetics on ammonia synthesis using iron catalyst, but also more importantly, perhaps, can induce some very useful and universal results. For example, firstly, Temkin equation is re- 
duced based on a two-step mechanism or those can be simplified as a two-step mechanism, and non-uniformity of the catalyst surface can usually be treat as a uniform surface in the kinetics of catalysis. Therefore it can be applied to any type of catalytic reactions. Secondly, as for multiple sites adsorption, the large difference on catalytic activity from different catalysts is driven from the multiple reasoning to active site, which is extremely important to the discussion of the structural sensitivity of heterogeneous catalytic reactions. Thirdly, the concept of distribution function on active site is introduced in the derivation of the Temkin theory, which can induce many well-known adsorption isotherms such as Freundlich, Frumkin-Temkin expressions and their formulas, and other laws of adsorption rate such as Elovich equation. It can deduce that optimum active site or best active catalyst should have moderate affinity value, which means energy distribution is in the center of active sites of the surface. These results can be considered as the Sabatier principle which best catalyst can be easily formed sufficiently stable but not too stable intermediates [64].

These theories provide valuable information for catalysis study that, the affinity value must be changed in order to get the best catalyst. For example, the following three methods can be used for the metal catalysts: First, changing the exposed crystal surface or the particle size to alter the surface structure, which includes the changes of the relative distribution ratio of atoms on the surface with different coordination numbers; Second, forming an alloy (e.g., copper is added into nickel ) or adding surface impurities (e.g., sulfur, carbon, oxygen or nitrogen) to the modified metal catalysts [9]; Third, according periodic table to changes metal components in the catalyst in order to select the best catalyst, such as the discovery of cobalt-molybdenum nitride catalyst. To make this approach meaningful, it must assume that reaction mechanism does not change. However, when the activity of a catalyst increases to a certain level, the further increase of them becomes very difficult. To break through this level, it has to find a different reaction mechanism.

Practice shows that there is no other reaction like ammonia synthesis reaction, which can link the theories, models and experiments together. The results obtained in the low-pressure experiments can be confirmed by high-pressure experiments; dynamics resulting obtained under the ultra-high vacuum condition can be extrapolated to the industrial conditions; studies on a single crystal can be described by the theory $[44,65]$. This situation can not only been applied to the iron catalyst, but also to the ruthenium catalyst and Co3Mo3N catalyst. Moreover, the required time to understand these catalysts is getting shorter, even though the structure and chemical composition of catalysts become more complex [13]. Therefore, the catalytic ammonia synthesis reaction is still an ideal model system for studying theories of heterogeneous catalysis.

(2) The ammonia synthesis reaction is one of the simplest chemical reactions which doesn't generate a by-product and is a green chemical reaction with $100 \%$ of atomic utilization. The cogeneration of ammonia synthesis with $\mathrm{CO}_{2}$ for urea or ammonium bicarbonate is a clean production process without any emission, which is a rare and matured industrial technology of combining the $\mathrm{CO}_{2}$ capture, storage and use [66]; In industry, achieving the ammonia synthesis reaction is one of the most complex and typical chemical process; In theory, the reaction is able to be completed at room temperature and atmospheric pressure but it practically is very difficult to be achieved unless at high temperature and high pressure conditions. Therefore, understanding the mechanism of the catalytic ammonia synthesis reaction and converting it into a perfect technology has been the primary standard on development of catalytic domain.

(3) The modern industrial iron catalysts are a nanostructured metastable substance, which is formed during the surprisingly complex synthesis of the oxide precursor $[67,68]$. Its metastability is also the reason on sensitivity of overheat stress generated during the activation and oxidative activation of materials. The pathway to prepare nanostructures can be selected, such as, $\mathrm{Fe}_{3} \mathrm{O}_{4} \rightarrow \mathrm{Fe}_{1-x} \mathrm{O}$ [69-72], and a seemingly very simple structure of the iron catalyst is actually very complicated. A startling example is that just using different catalyst precursors causes a tremendous change in the nanostructures of metal surface. Wustite-based catalyst has been demonstrated to be more active than the magnetite-based catalyst [23]. Quantitative analysis [73] reveals that, only less than $1 \%$ of the iron surface of the iron catalyst is involved in the activation of nitrogen, and the remaining $99 \%$ of the iron only plays the role of a support. If there can be more exposed surface on iron, the activity of the catalyst will be greatly enhanced. For instance, scientists used the iron catalyst as carrier, coated its surface with nano-iron to prepare coated nano-iron catalyst.

(4) Ammonia synthesis catalyst is the most stable catalyst in all industrial catalysts. The structure of such metastable materials with nanostructure is almost unchanged even being used under the harsh reaction conditions for more than 15 years. A lot of researches and characterizations regarding this property have been conducted, and many models have been proposed to explain the stability of the active surface and mechanism of its formation [10,55,74-79].

(5) The catalytic synthesis of ammonia which tightly associated with industry is still a key reaction for creating new life and a prototype model reaction that helps in gaining a fundamental understanding of catalysis in general and therefore of considerable scientific and cultural importance. It is mainly this reason that drives the research in ammonia synthesis forward, especially since evidence for a knowledge-based improvement of a catalyst would have a strong signaling effect on other fields of catalysis research [80].

For example, during ammonia synthesis process, from the gasification, purification to the synthesis, the major chemical reactions are heterogeneous catalytic process, so the catalyst plays a very important role. Nine catalysts are used in the steam conversion ammonia synthesis by using natural gas or naphtha as raw materials, which include hydrocarbon hydrogenation catalyst, steam reforming catalyst in first stage and second stage, high and low temperature shift catalyst, methanation catalyst, ammonia synthesis catalyst, CO selective oxidation catalyst, etc.; the partial oxidation process using residue as raw material and coal pressured gasification process 
also use sulphur-resistant CO shift catalysts, Claus sulfur recovery catalyst, $\mathrm{CO}_{2}$ dehydrogenation catalysts, various detoxification catalyst and molecular sieve drying agents [81]. Whichever the ammonia synthesis process, shift catalyst and ammonia synthesis catalyst are indispensable and are the core catalyst in ammonia industry.

This dozen of catalyst, most of them are basic catalysts in other chemical processes, such as coal chemical, petrochemical, natural gas chemical, bio-chemical, energy chemical, oil refining industry as well as environmental protection and other chemical process. In addition, ammonia synthesis industry also contains a series of high-tech and common key technologies need to be solved in emerging industries of strategic importance. The catalytic ammonia synthesis process itself also contains a huge potential for energy saving. People will continue to improve these catalysts. Therefore, the development of synthetic ammonia catalysts will promote the development of other catalysts. Understanding ammonia synthesis catalysts and process has a strong inspiration and reference on a series of common, key technologies in the modern chemical industry, energy, materials and environmental protection fields, especially for energy saving of traditional industries, modern coal chemical industry, hydrogen production and clean energy and other emerging industries of strategic importance [82].

\section{The challenges of the ammonia synthesis catalyst}

In the 21st century, ammonia synthesis was called as "sunset industry". Some scientists also lament all quiet at the nitrogen front and the low visibility of research in nitrogen fixation in general [83]. In this regard, the German scientist R. Schlögl [13] published a report entitled "Catalytic Synthesis of Ammonia-A Never-Ending Story?", pointed out the story of catalytic ammonia synthesis is never over.

(1) The nitrogen cycling is one of most important cycling in nature to sustain life on Earth. Ammonia is also an essential raw material for the operation of modern society, which gives the ammonia industry exuberant vitality. The synthesis of these materials requires ammonia as the activated state nitrogen. Catalytic ammonia synthesis is an important part of the nitrogen cycling in nature, also an important complement needed by organisms (including humans), and currently the only way to obtain activated state nitrogen in industrial-scale. Currently generating activated state nitrogen through other methods is still only the subject of scientific research. The production of ammonia requires the use of a variety of carbon-containing fuels to obtain $\mathrm{H}_{2}$ gas, however, no matter how scarce energy supplies and how strict the environmental controls will be, the rigid demand for food determines the ammonia industry must rely on scientific and technological progress to face this grim situation and continue its development and promote the continuous improvement and innovation on ammonia synthesis catalyst to meet the needs of human's existence and social development.

Therefore, ammonia industry is an irreplaceable traditional industry with vitality.

(2) Ammonia production of raw materials and fuels both are energy. Current global focuses on energy issues are closely relative to the ammonia industry. The emission of $\mathrm{CO}_{2}$ will also be severely restrict, saving energy and reducing emission have always been the major issues to the ammonia industry. The comprehensive energy consumption of advanced ammonia plant by using natural gas as a raw material has reached around $27.5 \mathrm{GJ} / \mathrm{t}$, with the process total thermal efficiency of more than $70 \%$ [84]. Commercial iron catalyst and ruthenium catalyst both can achieve the above benefits $[85,86]$. Any advancement in the catalyst can improve the thermodynamic efficiency and reduce the price of the product [87]. It should be emphasized that, superficially, the energy loss mainly comes from the transformation process and essentially should be from synthesis of ammonia. The power consumption which accounts the total energy consumption for about $30 \%$ is mainly for the service of synthesis [88]. The high pressure in ammonia synthesis is used to overcome the activation barrier of reaction, which depends on the catalyst activity. To overcome this reaction energy barrier we pay a how high price! Therefore, the development of new catalyst for low-pressure ammonia synthesis is meaningful.

(3) Haber-Bosch nitrogen fixation process does not involve the use of other forms of energy in catalytic reactions, such as electric energy, light energy, etc., neither the role of catalyst in different energy transformation. In reality production practice, the transformation of other forms of energy, such as the chemical energy, solar, wind, hydro and nuclear energy transferring into electric energy; or electric energy, light energy transferring into chemical energy; etc. is so extraordinarily interesting.

In the Haber-Bosch nitrogen fixation process which uses heat energy from fossil fuel as the sole driving force, even in the ammonia plant with the most advanced waste heat recovery and cascade utilization of energy (total energy efficiency is up to $74 \%$ ), there is not only more than $20 \%$ of the energy-saving potential, but also consumption of fossil fuels for at least 27.5 $\mathrm{GJ} / \mathrm{t}$ of energy. Even in the limit state (the total energy efficiency is $100 \%$ ), it still has to consume fossil fuels for $20.13 \mathrm{GJ} / \mathrm{t}$ of energy.

Therefore, the introduction of electric energy, solar energy, and radiation energy into ammonia synthesis to assist the activation of nitrogen molecule or change the reaction pathways, and the study of the role of a catalyst in the transformation between different forms of energy, are in the practical and theoretical significance.

(4) As everyone knows, focus and difficulties of catalytic chemistry research is the activation of the most stable of several small molecules in nature $\left(\mathrm{CO}_{2}, \mathrm{H}_{2} \mathrm{O}, \mathrm{CO}, \mathrm{CH}_{4}, \mathrm{H}_{2}, \mathrm{~N}_{2}, \mathrm{O}_{2}\right)$. Nitrogen molecule is one of hardest activated elemental substances and chemical bond. The dissociation energy of $\mathrm{N} \equiv \mathrm{N}$ triple bond is the $942 \mathrm{~kJ} / \mathrm{mol}$, and its break requires high energy. How to activate nitrogen molecule is a key theoretical issues to nitrogen fixation. Nitrogen molecule has also become one of the prototype molecules in chemistry and catalysis research with a typical representative significance.

(5) The standard equilibrium constant of ammonia synthesis reaction at $25^{\circ} \mathrm{C}$ is as high as $6.8 \times 10^{5}$. Therefore, the ammonia synthesis at room temperature and under atmospheric 
pressure is theoretically possible, but the reaction rate is almost impossible to be detected. This is a new challenge. Since nitrogen fixation is important for human survival and development, achieving ammonia synthesis at normal temperature and pressure has been the goal with relentless pursuit by human beings.

In summary, reducing energy consumption of the existing ammonia technology, looking for new ways and means of ammonia synthesis, exploring the possibility of ammonia synthesis at normal temperature and pressure, etc., are the new challenges faced by the catalytic ammonia technology.

The key to achieve ammonia synthesis at normal temperature and pressure is the activation of nitrogen molecule and forms and ways to provide energy.

\subsection{Activation of nitrogen molecule}

The process of converting the free state of nitrogen in air into nitrogen compounds is known as nitrogen fixation, including chemical and biological nitrogen fixation. There are mainly three ways to chemically activate nitrogen molecule:

(1) Reduction method, by using a reducing agent to give $\mathrm{N}_{2}$ electrons. Catalytic ammonia synthesis belongs to reduction method.

(2) Oxidation method, by using an oxidizing agent to take the electrons away from nitrogen molecule. Since the first ionization energy of $\mathrm{N}_{2}$ is high, such a strong oxidant has not been found to form a suitable catalytic cycle.

(3) physical-chemical method (activation method), by using strong conditions such as high Volt with discharge, plasma and other physical means to excite the $\mathrm{N}_{2}$ molecule from the ground state to the high energy state, or even take it apart to make it become a nitrogen atom or a nitrogen ion in order to react with other substances. For example: arc method and calcium cyanamide method at early stage. Enormous energy consumption greatly limits the industrial application of these two methods. In recent years, ammonia synthesis by the plasma [89-92], the magnetic induction method [93] and other studies are also active, but they are still in the exploratory stage.

Thus, the catalytic reduction method occupies undisputed dominance, which is also currently the only industrial-scale of chemical nitrogen fixation method. After a long time research and exploration, under the catalysis of ruthenium- and $\mathrm{Fe}_{1-\mathrm{x}} \mathrm{O}$-based catalysts, the initial active temperature of the catalysts can be reduced to about $200{ }^{\circ} \mathrm{C}$ [94]. For example, in the industrial process of high-purity ammonia, by using ZA- 5 catalyst, under the conditions of $8 \mathrm{MPa}$ of pressure and the reaction temperature at the inlet and exit of reactor is $215^{\circ} \mathrm{C}$ and $363^{\circ} \mathrm{C}$ respectively, the net value of ammonia is the more than $10 \%$, which has met the economic requirement for net value of ammonia in industry, the key is the development of the corresponding low pressures process. But it is expectedly difficult to further develop higher activity catalyst under lower temperatures.

The research on catalytic ammonia synthesis, which lasts for a century, is the study of the activation of $\mathrm{N}_{2}$ and its nature. Many kinds of modern physical-chemical instruments have

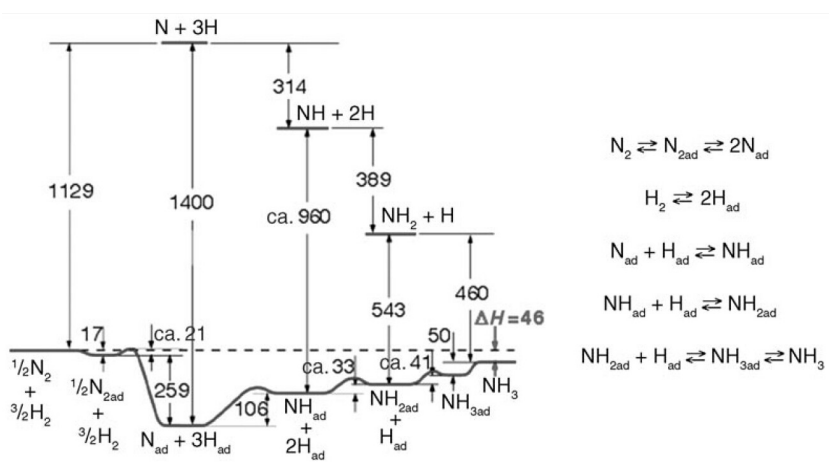

Fig. 1. Mechanism and potential energy diagram of ammonia synthesis on iron [98]. The energy is in $\mathrm{kJ} / \mathrm{mol}$.

been used to study the mechanism of activation of $\mathrm{N}_{2}$. However, so far, it still is controversial about the activation of nitrogen on iron catalysts, which is ever belonging to dissociative adsorption or molecular adsorption. The most of experiments support the dissociative adsorption [70,95-97]. For example, to Fe catalysts, G. Ertl [98] proposed a mechanism of catalytic ammonia synthesis reaction and potential energy diagram of its thermodynamics and kinetics based on $\mathrm{N}_{2}$ dissociative adsorption (Fig. 1). This is one of representative achievements when G. Ertl won the Nobel Prize in Chemistry in 2007 [99].

M. Boudart [80] considered that Figure 1 gave a lot of guidance. To really understand the mechanism of catalytic reaction, it should be able to provide a kind of thermal chemical kinetic profiles as clear as that of ammonia catalytic reaction shown Fig. 1. Theorists are trying to calculate a lot of missing energy value of the elementary steps in the catalytic cycle [100].

There are also many experiments to support the $\mathrm{N}_{2}$ molecular adsorption [65,101-106]. For example, Liao et al. [107,108] studied both mechanisms of ammonia synthesis, the associative and the dissociative, on iron catalysts surface by using the molecule design system for heterogeneous catalysis based on reactive energetics, the Bond Order Conservation-Morse Potential (BOC-MP) approach and anti- deuterium isotope effect [109]. The calculations showed that the activation energy barrier of rate-determining step (rds) on associative mechanism was below to that of rds on dissociative mechanism, but the activation energy barrier of reaction was significantly lower than that of rds on dissociative mechanism. It could be inferred that there are two competing reaction pathways on the surface of the iron catalyst.

In the ammonia synthesis by using iron catalyst, the stoichiometric number $\sigma_{\text {rds }}$ of overall reaction and rate-determining step which are detected from transfer of the chemical tracers can be equal to 1 or 2 (Fig. 2). Both values have been reported in the experimental work. Horiuti et al. $[110,111]$ found that $\sigma_{\text {rds }}=2$ near equilibrium. Tanaka [112] found that $\sigma_{\text {rds }}$ of synthesis reaction equals to 2 away from the equilibrium, but the $\sigma_{\text {rds }}$ of decomposition reaction equals to $1 . \sigma_{\text {rds }}=2$ is good for the rate-determining step in step 2 of Fig. 2(a), but many evidences indicates that the nitrogen adsorption is rate-determining step, where $\sigma_{\text {rds }}$ equals to 1 . However it cannot determine whether the adsorption is dissociation or not when $\sigma_{\mathrm{rds}}=$ 


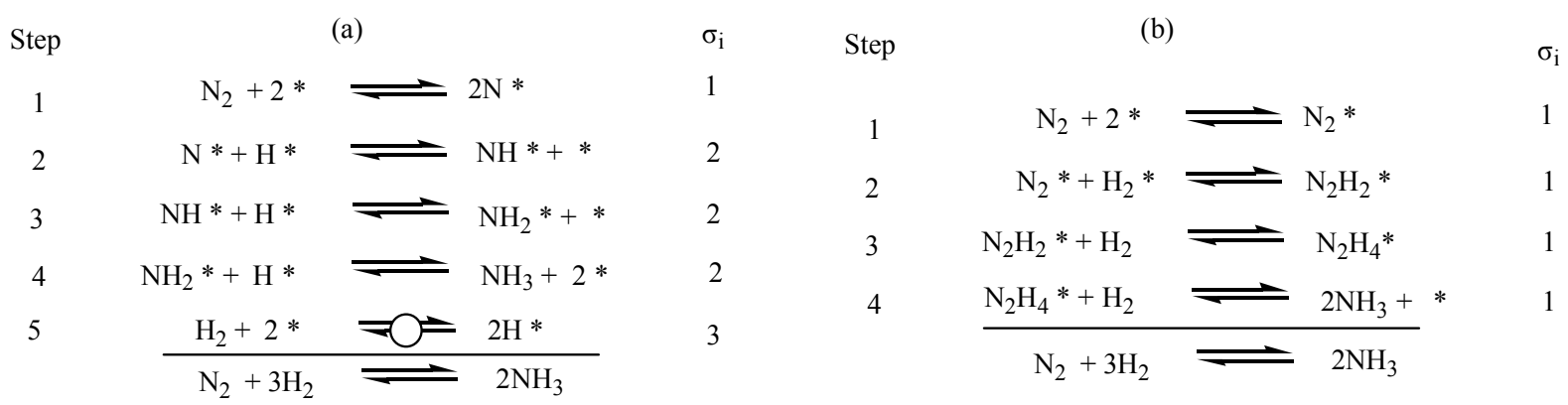

Fig. 2. The mechanisms of $\mathrm{N}_{2}$ dissociative adsorption (a) and molecular adsorption (b) and their stoichiometric number.

1. It is conceivable that the reaction sequence shown in Fig. 2(b) exists, wherein the first two steps are considered to be the pathway through which the nitrogenase realizes nitrogen fixation. If so, $\sigma_{\text {rds }}$ still equals to 1 . However, the evidence on the dissociative adsorption of nitrogen on iron catalyst is now overwhelming. The dissociation on iron catalysts and non-dissociation on the nitrogenase respectively just characterize industrial catalysis at high temperature and enzyme catalysis at low temperature. Therefore, in order to improve the activity of the iron catalyst on ammonia synthesis, it may need to essentially change the nature of each step in the iron-catalyzed reaction sequence [10].

Thus, the problems, such as the activated forms of $\mathrm{N}_{2}$ shown in Figs. 1 and 2, the basic steps of ammonia synthesis reaction and the real structure etc., still contain many science implies. The new and efficient method on activation of nitrogen molecule is still being explored [57]. The activation of nitrogen molecule is still a challenge in chemistry and catalysis science, and still has theoretical and practical significance.

\subsection{New challenges in theory of catalytic ammonia}

Although the heat value and the effective energy (exergy) of ammonia is 21.29 and $20.13 \mathrm{GJ} / \mathrm{t}$, respectively, the actual energy consumption is much higher. So no matter what materials and process are used to synthesize ammonia, the provided effective energy cannot be less than $20.13 \mathrm{GJ} / \mathrm{t}$. In the Haber-Bosch process of nitrogen fixation, because the effective energy value of the raw material is more than effective energy value of the product, ideal work of the process is positive. Each production of 1 ton of saturated liquid ammonia, theoretically, is external work process (Table 3). For example, the ammonia synthesis process by using pure $\mathrm{H}_{2}$ and $\mathrm{N}_{2}$ as raw materials can provide $0.63 \mathrm{GJ} / \mathrm{t}$ of external work, but directly using the water and air as raw materials for the nitrogen fixation process must consume external work of $20.31 \mathrm{GJ} / \mathrm{t}$ at least. The comparison shows that the main energy loss of the process derives from extractions of nitrogen in air and the hydrogen in water. Therefore, if other forms of energy, such as electric-, light-energy, etc., can be introduced into nitrogen fixation process to take the hydrogen out of water, then the reaction pathway can be changed. Although at least $20.31 \mathrm{GJ}$ of electric work needs to be consumed, electric energy can be derived from renewable energy sources, such as solar, wind, hydro or nuclear energy. If nitrogen fixation process do not have to use fossil fuels, that will be a completely revolution to ammonia industry!

Therefore, introducing the electric energy, solar energy, etc. into nitrogen fixation process, changing the reaction pathway or biomimetic synthesis is one of the major challenges thrown down to catalytic scientists and has great theoretical and practical significance.

\subsubsection{The studies of electrocatalysis catalysts}

Electrocatalysis can promote the thermodynamic nonspontaneous reaction $\mathrm{N}_{2}+3 \mathrm{H}_{2} \mathrm{O}=2 \mathrm{NH}_{3}+1.5 \mathrm{O}_{2}\left(K_{298}=10^{-120}\right)$ to occur by electric energy, thus expands the ammonia synthesis research field; It also allows the ammonia synthesis reaction which is limited by the equilibrium is not or less affected by the thermodynamic equilibrium. Therefore, the introduction of the electric energy into ammonia synthesis process to activate activation of nitrogen molecule or change the reaction pathway has been one of the concerned research areas. Electrochemical synthesis method has similar efficiency with that of existing methods and is a desirable method to synthesize ammonia under normal temperature and pressure [114]. For example, for the electrochemical process of ammonia synthesis at a high temperature $\left(570{ }^{\circ} \mathrm{C}\right)$ and atmospheric pressure, the conversion of hydrogen is close to $100 \%$. Thus, in recent years, studies of electrochemical method for ammonia synthesis at normal temperature and pressure ammonia are also very active

Table 3

Theoretical energy consumption of ammonia synthesis [113].

\begin{tabular}{|c|c|c|c|c|}
\hline Raw material & Total reaction equation of process & $\Delta H=\Delta H \mathrm{v}$ & $\begin{array}{c}\text { Theoretical energy consumption } \\
\text { of process }(\mathrm{GJ} / \mathrm{t})\end{array}$ & $\begin{array}{c}\text { Theoretical energy consumptio } \\
\text { of product }(\mathrm{GJ} / \mathrm{t})\end{array}$ \\
\hline Water, air & $\mathrm{H}_{2} \mathrm{O}+\mathrm{N}_{2} \rightarrow \mathrm{NH}_{3}+\mathrm{O}_{2}$ & 21.26 & 20.31 & 20.13 \\
\hline Water, air, coal & $\mathrm{C}+\mathrm{H}_{2} \mathrm{O}+\left(\mathrm{N}_{2}+\mathrm{O}_{2}\right) \rightarrow \mathrm{NH}_{3}+\mathrm{CO}_{2}$ & 0.80 & -0.19 & 20.13 \\
\hline Water, air, nature gas & $\mathrm{CH}_{4}+\mathrm{H}_{2} \mathrm{O}+\left(\mathrm{N}_{2}+\mathrm{O}_{2}\right) \rightarrow \mathrm{NH}_{3}+\mathrm{CO}_{2}$ & -1.85 & -0.94 & 20.13 \\
\hline Water, air, light oil & $\mathrm{C}_{9} \mathrm{H}_{2} \mathrm{O}+\mathrm{H}_{2} \mathrm{O}+\left(\mathrm{N}_{2}+\mathrm{O}_{2}\right) \rightarrow \mathrm{NH}_{3}+\mathrm{CO}_{2}$ & -1.41 & -1.65 & 20.13 \\
\hline Pure $\mathrm{H}_{2}$ and $\mathrm{N}_{2}$ & $\mathrm{H}_{2}+\mathrm{N}_{2} \rightarrow \mathrm{NH}_{3}$ & -3.95 & -0.63 & 20.13 \\
\hline
\end{tabular}




\section{[115-118].}

The main electro-catalysts which have been studied include iron phthalocyanine catalyst-loaded gas diffusion electrodes, the ceramic solid electrolyte and the molten salts ( $\mathrm{LiCl} / \mathrm{KCl} / \mathrm{CsCl})$ and so on. Using solid electrolytes with high proton conductivity at room temperature to improve the current efficiency and the stability of electrodes is an important direction for future research on electrochemical ammonia synthesis $[87,119,120]$.

Low current efficiency is the key to influence the efficiency and product costs of electrochemical ammonia synthesis. With the in-depth study of the electrochemical ammonia synthesis, if current efficiency and conversion rates can be significantly improved so that the cost of the electrochemical ammonia synthesis can be focused on consumption of electric energy, the electrochemical ammonia synthesis in the remote districts of sufficient in electric energy, or effectively converting solar energy, wind and water energy into electricity is expected to have its place. Especially when the energy crisis in the future leads to prices of oil, nature gas and coal etc. raise sharply which results in costs of Haber-Bosch ammonia synthesis growing exponentially, the electrochemical ammonia synthesis will be regarded as a useful alternative. Therefore, the study of electrochemical ammonia synthesis still has potential application [115].

\subsubsection{Research on photocatalytic ammonia synthesis catalysts}

The most familiar photocatalytic reaction is natural photosynthesis: $\mathrm{CO}_{2}+\mathrm{H}_{2} \mathrm{O} \rightarrow \mathrm{CH}_{2} \mathrm{O}+\mathrm{O}_{2}$. Green plants absorb sunlight by chlorophyll (photosensitizer), convert $\mathrm{CO}_{2}$ and $\mathrm{H}_{2} \mathrm{O}$ by plant enzymes to carbohydrate and release $\mathrm{O}_{2}$. Photosynthesis is the most important way to convert solar energy into chemical energy. The most critical step in complex process of photosynthesis is the substances in photosynthetic reaction center absorb photo energy to release electrons which are transferred into cells to cause chemical synthesis reaction so that solar energy is stored up [121].

At room temperature and atmospheric pressure using water as a hydrogen source and solar energy as energy, a photocatalytic way to directly transform the nitrogen in air into ammonia: $\mathrm{N}_{2}+3 \mathrm{H}_{2} \mathrm{O} \rightarrow 2 \mathrm{NH}_{3}+1.5 \mathrm{O}_{2}$, need to resolve the solar energy input and photocatalysts of problems.

These two reactions are both thermodynamically nonspontaneous reactions, and $\mathrm{N}_{2}$ is activated the harder than $\mathrm{CO}_{2}$, but their photocatalysis are both theoretically achievable. Whichever the natural $\mathrm{CO}_{2}$ reduction reaction or artificial water reduction (producing $\mathrm{H}_{2}$ ) and oxidation (producing $\mathrm{O}_{2}$ ) reaction, is a very complex catalytic process that usually occurs through multiple electrons pathway, and combinations of elementary reactions. Michel and Deisenhofer who co-winners of the Nobel Prize in Chemistry in 1988 [122,123] used theoretical calculations to conclude that the common effect of asymmetric nuclear Frank-condon factors and the electronic coupling is likely the main reason for unidirection electron transfer. The study results of mechanism of photosynthesis and its center structure will provide inspiration for photocatalytic ammonia synthesis.

The research on photocatalysis has more than 50 years of history [124]. Most of the photocatalyst used as the material having semiconductor characteristics, such as different series of metal-doped $\mathrm{TiO}_{2}$ and $\mathrm{WO}_{3}$ series [125], and CdS/GaP-Pt, $\alpha-\mathrm{Fe}_{2} \mathrm{O}_{3}-\mathrm{Nd}_{2} \mathrm{O}_{3}$ catalyst and so on [126-132] . Currently people are constantly developing more effective catalyst and the new methods for ammonia synthesis at normal temperature and pressure [133-135]. This shows that people are exploring to this long-term goal.

\subsubsection{Studies on chemical simulation of nitrogenase ammonia synthesis}

In nature, there is a microorganism, which comprises a catalyst with a special ability-nitrogenase, that can directly reduce the nitrogen in air to ammonia at normal temperature and pressure conditions. Its nitrogen fixation capacity is thousand-fold of Haber-Bosch chemical nitrogen fixation process. It is estimated that today the biological fixation of nitrogen reached 200 million tons, covering about $48 \%$ of the combined nitrogen in earth surface (the remaining $52 \%$ is provided by catalytic ammonia synthesis). Biological nitrogen fixation, both its required conditions and nitrogen fixation capability, is much higher than chemical nitrogen fixation. Biological nitrogen fixation can be divided into biological and biomimetic chemistry nitrogen fixation.

Biomimetic chemistry nitrogen fixation uses chemical methods to simulate the function of nitrogenase in vivo to prepare fine chemical catalyst in order to achieve ammonia synthesis at normal temperature and pressure. This is a challenge facing catalysis scientists. It is both theoretically and practically significance on studies about mechanism of biological nitrogen fixation. It can provide an important basis for the chemical simulation of biological nitrogen fixation. To achieve nitrogen fixation by nitrogen fixation microbes, there are three basic conditions [136]: (1) nitrogenase; (2) Mg-ATP2-; (3) electron donors, such as reduced ferredoxin, reduced flavodoxin, or artificial $\mathrm{Na}_{2} \mathrm{~S}_{2} \mathrm{O}_{4}$ to provide electrons for $\mathrm{N}_{2}$ reduction. The 1970s-1980s, a group of Chinese scientists led by famous scientists Aoqing Tang, Jiaxi Lu and Qirui Cai in-depthly studied the nitrogenase and its chemical simulation [137], and proposed a model of the active center of the nitrogenase [138]. After continuous efforts of scientists around the world, the chemical simulation of nitrogenase has been developed, and nitrogen fixation molecular genetics has been created, which have made biological nitrogen fixation research significant progress. Since the American scholar Rees et al [139-143] clarified the three-dimensional structure of nitrogenase active central atom clusters and polypeptides around, the studies about chemical simulation of biological nitrogen fixation are once again on the rise [144-151]. Meanwhile, the development of selective enzymes will be a rich source of catalysts for organic chemistry and biotechnology [152]. Although no satisfactory practical result has been achieved so far, the research and exploration for biological nitrogen fixation and biomimetic ammonia synthesis will not be stopped.

In addition, in the biological azotobacter nitrogen fixation method, mainly non-leguminous crops are inoculated by rhizobium using bio-engineering technology to introduce the nitro- 
genase genes and other related genes so that it can achieve self-provided nitrogen [153]. With the development of breeding transgenic technology to achieve non-leguminous crops with inoculation of rhizobium for self-provided nitrogen and a large number of planting leguminous and other oil plants (nitrogen-containing 7\%-8\%), and reducing the amount of chemical nitrogen fertilizer is one way to solve negative effects of a lot of fertilizer application in the agricultural production [154].

\section{Conclusions}

Ammonia synthesis in catalytic chemistry is charismatic. Fused iron catalysts have some special properties which are beyond compare to a number of other catalysts. The ammonia synthesis reaction of high industrial relevance is also a key reaction for creating new life and a prototypical model reaction that helps in gaining a fundamental understanding of catalysis in general and therefore of considerable science and culture importance. Understanding of the mechanism of catalytic ammonia synthesis and converting it into the perfect technology has been a basic standard in the catalytic domain, especially since evidence for a knowledge based improvement of a catalyst would have a strong signaling effect on other fields of catalysis research. Therefore, it is still an ideal model system for heterogeneous catalysis research.

Catalytic ammonia technology plays a central role in the development of the chemical industry in the 20th century. Humans need food, and food needs nitrogen, so the story of catalytic ammonia synthesis is never end. Ammonia is also an essential raw material for the operation of modern society, which gives exuberant vitality to ammonia industry, and will continue to promote the improvement and innovation on catalyst for ammonia synthesis. In the 21st century, catalytic ammonia technology will face new challenges in theory and practice and in new application of ammonia. Reducing the energy consumption of existing catalytic ammonia synthesis technology, introducing electric energy, light energy into ammonia synthesis process, looking for new ways of ammonia synthesis, exploring electrocatalysis, photocatalysis and chemical simulation biological nitrogen fixation on ammonia synthesis at normal temperature and pressure are concerned research field.

\section{References}

[1] Timm B. In: Proceedings of 8th International Congress on Catalysis. Vol. 1. Weinheim: Verlag Chemie, 1984. I-7

[2] Hu X D. In: The 15th National Conference on Catalysis of China. Guangzhou: South China University of Technology (胡效东. 见: 第十五届全国催化学术会议. 广州: 华南理工大学), 2010

[3] Zhejiang Institute of Chemical Engineering. Chem Fertilizer Catal (浙江化工学院. 化肥与催化), 1979, 1:1

[4] Xiang D H, Liu H Y. Handbook of Chemical Fertilizer Catalysts. Beijing: Chem Ind Press (向德辉, 刘惠云主编. 化肥催化剂实用手册. 北京: 化学工业出版社), 1992. 226

[5] Wei K M, Wang R, Chen Z Z, Ye B H, Zheng Q, Yu X J. Chem Fertilizer Ind (魏可镁, 王榕, 陈振宙, 叶炳火, 郑起, 俞秀金. 化肥工业), 1985, (3): 10

[6] Wei K M, Yu X J, Wang R, Lin J X, Wei M D. Ind Catal (魏可镁, 俞秀 金, 王榕, 林建新, 魏明灯. 工业催化), 1995, (3): 14

[7] Lin W M, Huang C R, Gan S F, Cao B L, Li Z P, Zhong H B. Guangdong Chem Ind (林维明, 黄传荣, 甘世凡, 曹柏林, 黎智萍, 钟慧 斌. 广东化工), 1984, (2): 6

[8] Figurski M J, Arabczyk W, Lendzion-Bielun Z, Kaleńczuk R J, Lenart S. Appl Catal A, 2003, 247: 9

[9] Pelka R, Kielbasa K, Arabczyk W. Cent Eur J Chem, 2011, 9: 240

[10] Lendzion-Bielun Z, Jedrzejewski R, Ekiert E, Arabczyk W. Appl Catal A, 2011, 400: 48

\section{Graphical Abstract}

Chin. J. Catal., 2014, 35: 1619-1640 doi: 10.1016/S1872-2067(14)60118-2

\section{Ammonia synthesis catalyst 100 years: Practice, enlightenment and challenge}

Huazhang Liu*

Zhejiang University of Technology
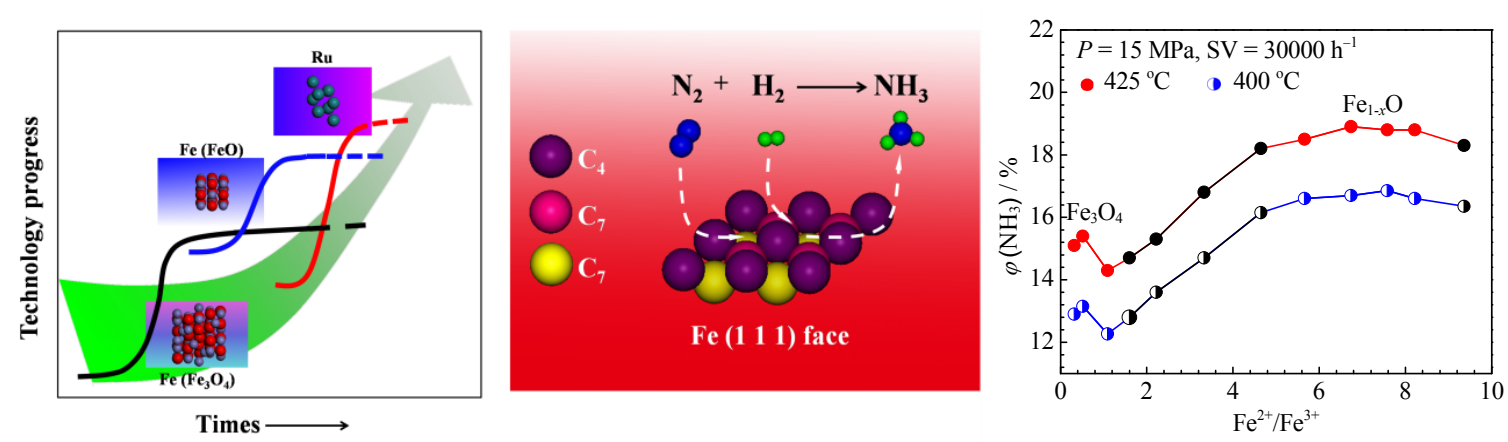

The achievement and progress of the ammonia synthesis catalysts in theory and practice during about 100 years, and a new challenge in face of a biomimetic ammonia-synthesis path at room temperature and atmospheric pressure, including electrocatalysis, photocatalysis and biocatalysis, are presented. Understanding the mechanism and the translation of the knowledge into technical perfection has become a fundamental criterion for scientific development in catalysis research. 
[11] Yu X J, Lin B Y, Lin J X, Wang R, Wei K M. J Rare Earths (俞秀金, 林 炳裕, 林建新, 王榕, 魏可镁. 稀土学报), 2008, 26: 711

[12] Zheng Y F, Liu H Z, Liu Z J, Li X N. J Solid State Chem, 2009, 182: 2385

[13] Schlögl R. Angew Chem Int Ed, 2003, 42: 2004

[14] Pernicone N, Ferrero F, Rossetti I, Forni L, Canton P, Riello P, Fagherazzi G, Signoretto M, Pinna F. Appl Catal A, 2003, 251: 121

[15] Shen J. Chemical Fertilizer Engineering Series: Ammonia Synthesis. Beijing: Chem Ind Press (沈浚主编. 化肥工学丛书一合 成氨. 北京: 化学工业出版社), 2001.49

[16] Liu H Z, Li X N. Sci China (Ser B), 1995, 38: 529

[17] Liu H Z, Li X N, Hu Z N. Appl Catal A, 1996, 142: 209

[18] Liu H Z, Li X N. Ind Eng Chem Res, 1997, 36: 335

[19] Liu H Z, Li X N. Stud Surf Sci Catal, 2000, 130: 2207

[20] Guan S, Liu H Z. Ind Eng Chem Res, 2000, 39: 2891

[21] Liu H Z, Liu C B, Li X N, Cen Y Q. Ind Eng Chem Res, 2003, 42: 1347

[22] Lendzion-Bielun Z, Arabczyk W, Figurski M. Appl Catal A, 2002, 227: 255

[23] Pernicone N. CATTECH, 2003, 7: 196

[24] Liu H Z. Ammonia Synthesis Catalysts: Innovation and Practice. Singapore: World Sci Publishing Co. Ltd., 2013

[25] Ozaki A, Aika K. In: Andersen J R, Boudart M eds. Catalysis, Science and Technology. Heidelberg: Springer, 1985. 88

[26] Bielawa H, Hinrichsen O, Birkner A, Muhler M. Angew Chem Int Ed, 2001, 40: 1061

[27] Sudo M, Ichikawa M, Soma M, Onishi T, Tamaru K. J Phys Chem, 1969, 73: 1174

[28] Aika K, Hori H, Ozaki A. J Catal, 1972, 27: 424

[29] Wan X N, Zhu H, Xia W Q Liu H Z. Chin J Catal (王晓南, 朱虹, 夏伟 琴, 刘化章. 催化学报), 2000, 21: 276

[30] Liang C H, Wei Z B, Xin Q, Li C. Appl Catal A, 2001, 208: 193

[31] Wan L H, Lin Y J, Jiang J, Chen H B, Lin Y Z, Chen S Z, Liao D W.J Xiamen University (Natur Sci) (王丽华, 林贻基, 江剑, 陈鸿博, 林 银钟, 陈守正, 廖代伟. 厦门大学学报(自然科学版)), 1999, 38: 148

[32] Liu G Z, Zheng X L, Xu J X, Wei K M. Ind Catal (刘广臻, 郑晓玲, 许 交兴, 魏可镁. 工业催化), 2004, 12(6): 44

[33] Forni L, Molinari D, Rossetti I, Pernicone N. Appl Catal A, 1999, 185: 269

[34] Rossetti I, Pernicone N, Forni L. Appl Catal A, 2001, 208: 271

[35] Brown D E, Edmonds T, Joyner R W, McCarroll J J, Tennison S R. Catal Lett, 2014, 144: 545

[36] Jacobsen C J H, Dahl S, Clausen B S, Bahn S, Logadottir A, Nörskov J K. J Am Chem Soc, 2001, 123: 8404

[37] Kojima R, Aika K. Appl Catal A, 2001, 219: 141

[38] Kojima R, Aika K. Appl Catal A, 2001, 219: 157

[39] Kojima R, Aika K. Appl Catal A, 2001, 218: 121

[40] Kojima R, Aika K. Appl Catal A, 2001, 215: 149

[41] Kojima R, Aika K. Chem Lett, 2000: 514

[42] Kojima R, Aika K. Appl Catal A, 2001, 209: 317

[43] Kojima R, Aika K. Chem Lett, 2000: 912

[44] Ertl G.J Vac Sci Technol A, 1983, 1: 1247

[45] Strongin D R, Carrazza J, Bare S R, Somorjai G A. J Catal, 1987, 103: 213

[46] Logadottir A, Rod T H, Norskov J K, Hammer B, Dahl S, Jacobsen C J H. J Catal, 2001, 197: 229

[47] Jacobsen C J H. Chem Commun, 2000: 1057

[48] Thomas J M, Zamaraev K I. Angew Chem Int Ed, 1994, 33: 308

[49] Zheng Q F. [PhD Dissertation]. Hangzhou: Zhejiang Univ Technol (郑启富. [博士学位论文]. 杭州: 浙江工业大学), 2012

[50] Hecht D. Drug Develop Res, 2011, 72: 53

[51] Horiguchi J, Kobayashi S, Yamazaki Y, Nakanishi T, Itabashi D,
Omata K, Yamada M. Appl Catal A, 2010, 377: 9

[52] Huang K, Zhan X L, Chen F Q, Lü D W. Chem Eng Sci, 2003, 58: 81

[53] Aparicio L M, Dumesic J A. Top Catal, 1994, 1: 233

[54] Boudart M. Top Catal, 1994, 1: 405

[55] Somorjai G A, Materer N. Top Catal, 1994, 1: 215

[56] Tamaru K. In: Jennings J R ed. Catalytic Ammonia Synthesis. New York: Plenum Press, 1991. Chapter 1

[57] Rosenthal D. Phys Status Solid A, 2011, 208: 1217

[58] Nielsen A. An Investigation on Promoted Iron Catalysts for the Synthesis of Ammonia. 3rd Ed. Copenhagen: Jul Gjellerup's Forlag, 1968

[59] Anderson J R, Boudart M. Catalysis, Science and Technology. Berlin: Springer-Verlag, 1983

[60] Jennings J R. Catalytic Ammonia Synthesis, Fundamental and Practice. New York: Plenum Press, 1991

[61] Aika K, Christiansen L. Ammonia Catalysis and Manufacture. Berlin: Springer-Verlag, 1995

[62] Topsöe H, Boudart M, Norskov J K. Ammonia Synthesis and Beyond. Amsterdam: Baltzer Sci Publishers, 1994

[63] Jacobsen C J H, Dahl S, Hansen P L, Törnqvist E, Jensen L, Topsøe H, Prip D V, Møenshaug P B, Chorkendorff B. J Mol Catal A, 2000, 163: 19

[64] Boudart M, Djega-Mariadassou G. Kinetics of Heterogeneous Catalytic Reactions. Princeton: Priceton Univ Press, 1984

[65] Alstrup I, Chorkendorff I, Ullmann S. J Catal, 1997, 168: 217

[66] Jing Y, Arons D J S. Resource, Energy, Environment, Society-Scientific and Engineering Principles for Circular Economy. Beijing: Chem Ind Press (金涌, 阿伦斯. 资源·能源·环境·社会一循 环经济科学工程原理. 北京: 化学工业出版社), 2009

[67] SchlJgl R. In: Ertl G, KnJzinger H, Weitkamp J eds. Handbook of Heterogeneous Catalysis. Weinheim: Wiley-VCH, 1997. 1697

[68] Holme B, Skaugset P, Tafto J. Appl Catal A, 1997, 162: 149

[69] Jedynak A, Kowalczyk Z, Szmigiel D, Zielinski J. Pol J Chem, 2001, 75: 1801

[70] Guan S, Lin H Z. Ind Eng Chem Res, 2000, 39: 2891

[71] Jacobsen C J H, Jiang J Z, Morup S, Clausen B S, Topsoe H. Catal Lett, 1999, 61: 115

[72] Yunusov S M, Kalyuzhnaya E S, Mahapatra H, Puri V K, Likholobov V A, Shur V B. J Mol Catal A, 1999, 139: 219

[73] Liu H Z, Li X N, Shzyki S, Ohnishi R, Ichikawa M. J Chem Ind Eng (China) (刘化章, 李小年, 铃木聪雄, 大西隆一郎, 市川胜. 化工学 报), 2000, 51: 462

[74] Arabczyk W, Narkiewicz U, Moszynski D. Langmuir, 1999, 15: 5785

[75] Arabczyk W, Narkiewicz U, Kalucki K. Vacuum, 1994, 45: 267

[76] Silverman D C, Boudart M. J Catal, 1982, 77: 208

[77] Holme B, Taft J. J Catal, 1995, 152: 243

[78] Arabczyk W, Narkiewicz U, Moszynski D. Appl Catal A, 1999, 182: 379

[79] Herzog B, Herein D, SchliSgl R. Appl Catal A, 1996, 141: 71

[80] Boudart M. Top Catal, 2000, 13: 147

[81] Yu Z H, Zhu B C, Shen C D et al. Process Analysis for Large Synthetic Ammonia Plant. Beijing: China Petrochem Press (于遵宏, 朱 炳辰, 沈才大等. 大型合成氨厂工艺过程分析. 北京: 中国石化出 版社), 1993

[82] Liu H Z. Chem Ind Eng Progr (刘化章. 化工进展), 2013, 32: 1995

[83] Leigh J. Chem Br, 2001, 37: 23

[84] Dybkjaer I. In: Nielsen A ed. Ammonia, Catalysis and Manufacture. Heidelberg: Springer, 1995. 199

[85] Mittasch A. Z Elektrochem Amgew Phys Chem, 1930, 36: 569

[86] Mittasch A. Adv Catal, 1950, 2: 81

[87] Marnellos G, Stoukides M. Science, 1998, 282: 98 
[88] Liu H Z. Chem Ind Eng Progr (刘化章. 化工进展), 2011, 30: 1147

[89] Mizushima T, Matsumoto K, Ohkita H, Kakuta N. Plasma Chem Plasma Process, 2007, 27: 1

[90] Yuan J H, Zhong X J, Tan S Y. J Chem Ind Eng (原金海, 仲学军, 谭 世语. 化学工业与工程), 2008, 29(4): 7

[91] Carrasco E, Jiménez-Redondo M, Tanarro I, Herrero V J. Phys Chem Chem Phys, 2011, 13: 19561

[92] Kubota Y, Koga K, Ohno M, Hara T. Plasma Fusion Res, 2010, 5: 042

[93] Yahya N, Puspitasari P, Noordin N H. Defect Diffusion Forum, 2013, 334-335: 329

[94] Liu H Z, Hu Z N, Li X N, Cen Y Q, Fu G P. J Chem Ind Eng (China) (刘化章, 胡樟能, 李小年, 岑亚青, 傅冠平. 化工学报), 2001, 52: 1063

[95] Por E, Haase G, Citri O, Kosloff R, Asscher M. Chem Phys Lett, 1991, 188: 553

[96] Katz G, Kosloff R. J Chem Phys, 1995, 103: 9475

[97] Vandervell H D, Vaugh K C. Chem Phys Lett, 1990, 171: 462

[98] Ertl G. Catal Rev Sci Eng, 1980, 21: 201

[99] Ertl G. Angew Chem Int Ed, 2008, 47:3524

[100] Rappe A K, Goddard W A. In: Truhlar D G ed. Potential Energy Surfaces and Dynamics Calculations. New York: Plenum, 1981. 661

[101] Mortensen J J, Hansen L B, Hammer B, Nørskov J K. J Catal, 1999, 182: 479

[102] Shen H B, Liao Y Y, Zhang H B, Tsai K R. Chin Chem Lett, 1993, 4: 457

[103] Zhang H B, Schrader G L. J Catal, 1986, 99: 461

[104] Spencer M S. Catal Lett, 1992, 13: 45

[105] Seiyama T, Tanabe K. Proceedings of the 7th International Congress on Catalysis. Nitrogen Fixation. Tokyo, 1980

[106] Bowker W. Top Catal, 1994, 1: 265

[107] Sun J, Xu M, Liao D W. Comput Appl Chem (孙杰, 许猛, 廖代伟. 计算机与应用化学), 2004, 21: 245

[108] Hei M J, Cheng H B, Lin Y J, Hong Q Lin Y Z, Yi J, Liao D W, Tsai K R. J Xiamen Univ (Natur Sci) (黑美军, 陈鸿博, 林贻基, 洪琦, 林 银钟, 易军, 廖代伟, 蔡启瑞. 厦门大学学报(自然科学版)), 1997, 36: 879

[109] Lin J D, Liao D W, Zhang H B, Wan H L, Tsai K R. Chin J Catal (林敬 东, 廖代伟, 张鸿斌, 万惠霖, 蔡启瑞. 催化学报), 2010, 31: 153

[110] Enomoto S, Horiuti J. J Res Inst Catal (Hokkaido Univ), 1953, 2: 87

[111] Enomoto S, Horiuti J. J Res Inst Catal (Hokkaido Univ), 1954, 3: 185

[112] Tanaka K.J Res Inst Catal (Hokkaido Univ), 1966, 13: 119

[113] Liu H Z. Ammonia Synthesis Catalysts: Practice and Theory. Beijing: Chem Ind Press (刘化章. 氨合成催化剂一实践与理论. 北京: 化学工业出版社), 2007

[114] Rod T H, Logadottir A, Norskov J K. J Chem Phys, 2000, 112: 5343

[115] Zhang S Y. Chemistry Online (张树永. 化学通报), 2001, c01005

[116] Skulason E, Bligaard T, Gudmundsdottir S, Studt F, Rossmeisl J, Abild-Pedersen F, Vegge T, Jonsson H, Norskov J K. Phys Chem Chem Phys, 2012, 14: 1235

[117] Cui Y C, Liu R Q. J Xinjiang Univ (崔银仓, 刘瑞泉. 新疆大学学报 (自然科学版)), 2010, 27: 473

[118] Neurock M. In: 15th International Congress on Catalysis. Munich, Germany, 2012

[119] Murakami T, Nohira T, Ogata Y H, Ito Y. Electrochem Solid State Lett, 2005, 8: E1

[120] Yiokari C G, Pitselis G E, Polydoros D G, Katsaounis A D, Vayenas C G. J Phys Chem A, 2000, 104: 10600
[121] Malato S. In: 15th International Congress on Catalysis. Munich, Germany, 2012

[122] Deisenhofer J, Epp 0, Miki K, Huber R, Michel H. Nature, 1986, 318: 618

[123] Michel H, Epp 0, Deisenhofer J. EMBO J, 1986, 5: 2445

[124] Herrmann J. In: 15th International Congress on Catalysis. Munich, Germany, 2012

[125] Maeda K. In: 15th International Congress on Catalysis. Munich, Germany, 2012

[126] Xu H B, Yang W S, Guo Q, Dai D X, Chen M D, Yang X M. J Am Chem Soc, 2013, 135: 10206

[127] Yamauchi M, Abe R, Tsukuda T, Kato K, Takata M. J Am Chem Soc, 2011, 133: 1150

[128] Noda Y, Lee B, Domen K, Kondo J N. Chem Mater, 2008, 20: 5361

[129] Rao N N, Dube S, Manjubala, Natarajan P. Appl Catal B, 1994, 5: 33

[130] Ileperuma O A, Tennakone K, Dissanayake W D D P. Appl Catal, 1990, 62: L1

[131] Schrauzer G N, Guth T D. J Am Chem Soc, 1977, 99: 7189

[132] Yamauchi M, Abe R. EP Patent 2474356 A1. 2012

[133] Domen K. In: 15th International Congress on Catalysis. Munich, Germany, 2012

[134] Li C. In: 15th International Congress on Catalysis. Munich, Germany, 2012

[135] Periana R. In: 15th International Congress on Catalysis. Munich, Germany, 2012

[136] Group of Nitrogen Fixation at Jilin University. Progress in Chemical Simulation of Biological Nitrogen Fixation. Beijing: Sci Press (吉林大学化学系固氮小组等编译. 化学模拟生物固氮进展. 北 京: 科学出版社), 1973

[137] Research Group of Nitrogen Fixation at Fujian Institute of the Structure of Matter, CAS. Progress in Chemical Simulation of Biological Nitrogen Fixation. Beijing: Sci Press (中国科学院福建物 质结构研究所固氮研究小组编译. 化学模拟生物固氮进展. 北 京: 科学出版社), 1976

[138] Zhou T J, Wan H L, Wang N Q, Liao D W, Tsai K R. J Xiamen Univ (Natur Sci) (周泰锦, 万惠霖, 王南钦, 廖代伟, 蔡启瑞. 厦门大 学学报(自然科学版)), 1987, 26: 195

[139] Wang Y S, Li J L. Progr Natur Sci (王友绍, 李季伦. 自然科学进 展), 2000, 10: 481

[140] Kim J, Rees D C. Nature, 1992, 360: 553

[141] Kim J, Rees D C. Science, 1992, 257: 1677

[142] Howard J B, Rees D C. Proceedings of the National Academy of Sciences of the United States of America. 2006, 103: 17088

[143] Rees D C, Tezcan F A, Haynes C A, Walton M Y, Andrade S, Einsle O, Howard J B. Philosophical Transactions of the Royal Society A, 2005, 363: 971

[144] Hamilton T L, Lange R K, Boyd E S, Peters J W. Environ Microbiology, 2011, 13: 2204

[145] Cheng Q. J Integrative Plant Biology, 2008, 50: 786

[146] Tuczek F. Nachrichten aus der Chem, 2006, 54: 1190

[147] de Matos Nogueira E, Olivares F L, Japiassu J C, Vilar C, Vinagre F, Baldani J I, Silva Hemerly A. Plant Sci, 2005, 169: 819

[148] Studt F, Tuczek F. Angew Chem Int Ed, 2005, 44: 5639

[149] Dixon R, Kahn D. Nature Rev Microbiol, 2004, 2: 621

[150] Gehring C, Vlek P L G. Basic Appl Ecol, 2004, 5: 567

[151] Vinther F P. Plant Soil, 1998, 203: 207

[152] Reetz M T. In: 15th International Congress on Catalysis. Munich, Germany, 2012

[153] Wang T F. Chem Ind Eng Progr (王庭富. 化工进展), 2001, (8): 6 [154] Wu H Y. Chem Eng Design (伍宏业. 化工设计), 2002, 12(4): 3 


\title{
氨合成催化剂100年: 实践、启迪和挑战
}

\author{
刘化章* \\ 浙江工业大学工业催化研究所, 浙江杭州 310014
}

\begin{abstract}
摘要: Haber-Bosch发明的氨合成催化剂创立已经100周年. 介绍了氨合成催化剂在理论和实践方面的发展、成就及其启迪, 展望了 氨合成催化剂的未来和面临的新挑战. 催化合成氨技术在 20 世纪化学工业的发展中起着核心的作用. 一个世纪以来, 氨合成催化 剂经历了 $\mathrm{Fe}_{3} \mathrm{O}_{4}$ 基熔铁催化剂、 $\mathrm{Fe}_{1-\mathrm{x}} \mathrm{O}$ 基熔铁催化剂、 $\mathrm{Ru}$ 基催化剂等发展阶段, 以及钴锄双金属氮化物催化剂的发现. 实践表明, 氨 合成催化剂是多相催化领域中许多基础研究的起点和试金石, 没有别的反应象氨合成反应一样, 能够把理论、模型催化剂和实验 连接起来. 催化合成氨反应仍然是多相催化理论研究的一个理想的模型体系. 理解该反应机理并转换成完美技术成为催化研究 领域发展的基本标准. 这个永不结束的故事仍然没有结束. 除了关于反应的基本步骤、真实结构、亚氮化物这些问题之外, 催化 合成氨在理论上一个新的挑战是关于在室温和常压下氨合成的预测, 包括电催化合成氨、光催化合成氨和化学模拟生物固氮以及 包括氮分子在内的催化化学研究中几种最稳定的小分子的活化方法等.
\end{abstract}

关键词: 氨合成催化剂; 发明; 发展; 挑战; 实践; 启迪

收稿日期: 2014-03-19. 接受日期: 2014-04-23. 出版日期: 2014-10-20.

*通讯联系人. 电话: (0571)88320063; 传真: (0571)88320259; 电子信箱: cuihua@zjut.edu.cn

本文的英文电子版由Elsevier出版社在ScienceDirect上出版(http://www.sciencedirect.com/science/journal/18722067).

\section{1. 氨合成催化剂的发明与启示}

硅1913年9月9日, 世界上第一座合成氨装置投产. 之后, 合成氨工业迅速发展, 到 21 世纪初, 日产合成氨 1000 和 $2200 \mathrm{t}$ 的装置遍布全球. 合成氨成为一个庞大的 支柱化学工业. 这是人类征服自然的一个划时代的丰 碑.

在这项伟大的发明过程中, 曾遭遇了前所未有的困 难 ${ }^{[1]} .1787$ 年, C. L. Berthollet提出氨是由氮和氢元素组 成的. 当时杰出化学家, 包括W. H. Nernst, W. Ostward 和F. Haber等, 立即以极大的努力专心致力于通过元素 氮和氢合成氨的研究, 然而却首先遭遇了化学平衡的障 碍和争议. 因为当时质量作用定律和化学平衡的规律尚 未发现, 在平衡时氨的浓度究竟有多大不清楚. 在常压 下只有在相当低的温度时才生成氨, 而在高温下氨分子 会发生分解. 因此, 当时许多科学家甚至认为由元素生 成氨存在着不可逾越的障碍.

在这个关键时刻, Haber第一个提出了高压反应技 术. 但是, 氨的单程合成率太低仍不能实现工业规模生 产; 于是他抛弃了当时化学科学上流行的静止观点而采 用考虑动力学的动态方法, 引入了反应速率即时-空产 率(space-time yield)的概念, 替代了反应产率概念. 根据 这个重要原理, 提出了封闭流程和循环操作工艺技术. 这三项技术和反应速率的概念是一个伟大的创造, 正是 以此为基础, 实现了工业史上第一个加压催化过程. 这 是催化工艺发展史上的一个里程碑, 它标志着工业催化 新纪元的开端. 仅在几年之后, 相继出现的甲醇合成、费
托合成油和在多相催化剂存在下的高压反应技术就成 为有机化学领域中的基本实践, 推动了整个化学工业和 材料工业的发展. Haber的这一系列史无前例的创造奠 定了整个化学工程科学的基础!

1908 年 2 月, Haber 与德国巴登苯胺纯碱公司 (Badische Anilin und Soda Fabrik, 简称巴斯夫BASF)签 订了协议. BASF把工业开发的任务交给化学家 Carl Bosch. Bosch立即认识到他必须着手解决 3 个主要难题: 设计出生产廉价氢和氮的方法; 寻找一种高效且稳定的 催化剂; 开发适用于高压临氢合成氨反应的设备和材 料.

Haber等精力充沛地进行了催化剂的探索. Haber发 现了锇和铀-碳化铀催化剂对合成氨反应显示出优异性 能. BASF公司获得了全世界所有Os存货的购买权, 总 计大约 $100 \mathrm{~kg}$. 这在现在听起来是不可思议的, 充分反 映了当时科学家和企业家的激情. 但是, 1912年Haber被 任命为Kaiser Wilhelm研究所的物理化学与电化学研究 所所长, 这也标志了 Haber在氨合成领域中研究活动的 结束.

Bosch把寻找高效且稳定的催化剂的任务交给助手 Alwin Mittasch. Mittasch首先在金属氮化物上进行了广 泛研究, 试图通过这种间接途径来固定空气中的氮. 虽 然这对于氨合成技术是不成功的, 但提供了关于周期表 中几乎所有金属元素催化性质的有价值信息. 他认识到 许多金属本身只呈现较少的或者没有催化效应, 然而某 种添加剂能提高它们的催化活性. 在这些发现的基础 上, 1909年2月他提出一个未经证明的假设: “获胜的催 
化剂是多组分体系”, 并需要进行极大量的系列试验. 为 此, BASF公司为催化剂试验制作了各种模型反应器, 到 1911年, 在约一年半时间内, 对 2500 个不同催化剂进行 了 6500 次试验. 这一针对催化剂选择的惊人的试验, 一 直进行到1922年才告结束, 前后共试验了20000多次, 研 究了5000多个不同催化剂体系.

铁是合成氨反应有效的催化剂, 在 1905 年就为人所 知. 但在BASF公司初期的实验中, 被证明是令人失望 的. 这时Mittasch的助手Wolf无意中用数年前就放在实 验室搁板上的瑞典产的Gallivare铁矿石样品做试验, 得 到了意外的结果. 当纯铁与百分之几的氧化铝, 少量钾 碱和氧化钻共熔时, 就得到了一个适用于合成氨的催化 剂. 最好的催化剂被证明是一个多组分混合物, 其组成 与Gallivare的磁铁矿相近. 这就是沿用至今的少量助催 化剂促进的磁铁矿基熔铁催化剂. 这个混合催化剂被证 明是如此有效, 乃至现在全世界所有的氨催化剂还仍然 依据这个原理制造.

Haber, Bosch, Mittasch和Ertl这4位伟大的科学家为 合成氨工业的创立和发展作出了巨大的贡献, 其中 Haber, Bosch和Ertl分别获得诺贝尔化学奖.

合成氨工业的开发成功, 既是技术上的成就, 也是 组织工作上的一项杰作, 它成为当今较为通用的协同创 新(team work)的早期先例. 在创立过程中, Haber, Bosch 和Mittasch伟大的创造性、光辉的科学思想和创新精神, 科学家和企业家的激情和合作精神, 以及化学家、工程 师、物理学家、材料学家与各种工匠群体合作、协同创 新的团队精神等, 都是值得我们敬佩和学习的.

合成氨工业的巨大成功, 改变了世界粮食生产的历 史. 据联合国粮农组织(FAO)的统计, 化肥对粮食生产 的贡献率占 $40 \%$ 以上. 因此, Haber-Bosch发明的催化合 成氨技术被认为是催化技术对人类最伟大的贡献之一. 从 20 世纪初该技术发明到现在, 地球上的人口从 17 亿增 长了 4.2 倍, 而粮食的产量却增长了7.8倍, 人类至今可以 在有限的土地资源上丰衣足食, 其主要贡献者就是发明 该技术的Haber和Bosch. 现在我们人体中 $50 \%$ 的氮来自 于合成氨 ${ }^{[2]}$, 也就是说, 如果没有这项发明, 地球上将有 $50 \%$ 的人不能生存. 我国也不可能以占世界 $7 \%$ 的耕地 养活占世界 $20 \%$ 的人口.

经过百年的发展, 催化合成氨技术取得了巨大的进 步. 单套生产装置的规模已由当初的日产合成氨 5 t发展 到目前的 $2200 \mathrm{t}$, 反应压力已由当初的 $100 \mathrm{MPa}$ 降到了 10-15 MPa, 能耗已从当初的 78 GJ降到 27.2 GJ, 已接近
理论能耗 $20.1 \mathrm{GJ}$. 但作为第二个最大化学品的合成氨 的生产过程中, 仍然要消耗占全球能源供应总量的 $2 \%$, 排放 $\mathrm{CO}_{2}$ 超过 $(400 \mathrm{Mt})$, 占全球 $\mathrm{CO}_{2}$ 排放总量的 $1.6 \%$.

\section{2. 氨合成催化剂的发展与实践的启示}

熔铁催化剂的发明, 开创了催化合成氨工业. 合成 氨铁催化剂成为世界上研究得最成功、最透彻的催化剂 之一. 虽然随着石油化工、新型煤化工、生物化工、高 分子、材料、能源、环境等催化领域的崛起, 合成氨催 化剂的研究在催化领域的相对地位逐渐下降, 目前已不 再是催化研究的主要方面, 但粮食的刚性需求决定了不 可替代的传统合成氨工业只能依靠科技进步不断发展. 而催化剂的任何一个进步都能够提高热力学效率和降 低产品的价格. 因此, 合成氨工业及其催化剂技术进步 不会停止. 当初, Haber从试验过的约5000个催化剂中才 找出适合于生产的 $\mathrm{Fe}$ 催化剂, 今天为了进一步完善这个 工艺和降低能耗, 依然只有寄希望于催化剂的进一步改 进上.

\section{1. 氨合成催化剂的发展}

目前, 工业上熔铁催化剂仍占绝对地位, 催化剂产 品型号不少于数十种, 仅我国就有十余种. 我国南京化 学工业公司于1951年研制了A102型氨合成催化剂. 这 是我国自行研制的第一个氨合成催化剂, 此后又研制成 功A106型和A109型氨合成催化剂. 1979年, 浙江工业大 学研制成功A110-2型低温氨合成催化剂 ${ }^{[3]}$, 此后南京化 工研究院、福州大学、临朐催化剂厂、郑州大学和湖北 化学研究所等相继研制成功A110-1, A110-3, A110-4, A110-5Q (球形)和A110-6型, 形成了我国20世纪80年代 以来广为应用的A110系列催化剂 ${ }^{[4]}$.

含钴催化剂的开发是传统 $\mathrm{Fe}_{3} \mathrm{O}_{4}$ 基熔铁催化剂的一 个重要发展. 1978年, 英国ICI公司申请了有关含钴催化 剂的专利, 1979年开发成功74-1型含钴催化剂. 1985年, 福州大学研制成功 $\mathrm{A} 201$ 型含钴催化剂 ${ }^{[5]}$, 此后进一步降 低了A201型催化剂中钴的含量并添加 $\mathrm{CeO}_{2}$ 改进其性能, 并于1995年推出了A202型含钴催化剂 ${ }^{[6]}$. 此外, 华南理 工大学、南化公司研究院、郑州大学等也相继开发了含 钴催化剂[4,7].

自 20 世纪 90 年代钓基氨合成催化剂发明以来, 国内 外在本领域的主要研究方向和注意力都转移到钉催化 剂的研究上, 熔铁催化剂的研究反而成了冷门. 目前, 全 世界只有少数大学及研究所仍在研究熔铁催化剂, 其中 主要是波兰Szczecin理工大学 ${ }^{[8-10]}$ 、福州大学 ${ }^{[1]}$ 和浙江 
工业大学 ${ }^{[12]}$; 其它如德国马普学会的Fritz Haber研究所 等 ${ }^{[13]}$ 偶有有关氨合成铁催化剂的研究论文发表.

熔铁催化剂到20世纪60-70年代已基本定型, 工业 上使用的铁催化剂与 100 年前BASF开发的没有根本不 同 $^{[14]}$. 技术已经发展到成熟阶段, 要想取得显著的进步 将会变得更为困难. 这将促使人们寻求重大的技术突破 - 一种跳跃式或非连续性的技术进步. 近 30 多年来, $\mathrm{Fe}_{1-x} \mathrm{O}$ 基催化剂体系、钉基催化剂以及钴钼双金属氮化 物催化剂的发现, 正是这种寻求技术突破的思想体现 (表1).

\subsection{1. $\mathrm{Fe}_{1-x} \mathrm{O}$ 基氨合成催化剂的发现}

近百年来, 国内外学者一直认为熔铁催化剂的母体 为 $\mathrm{Fe}_{3} \mathrm{O}_{4}$ 时催化剂具有最高的活性. 在过去的熔铁催化 剂研究开发中, 人们局限于 $\mathrm{Fe}_{3} \mathrm{O}_{4}$ 催化剂的思维, 仅通过 改变助催化剂的种类和数量来改善催化剂的活性和寿 命, 而忽视了催化剂母体相的影响. 虽然各国一直在不 停地研究和改进, 但一直是磁铁矿一统天下 ${ }^{[15]}$. 1986年, 浙江工业大学 ${ }^{[16-21]}$ 发明的具有维氏体(Wustite)结构的 $\mathrm{Fe}_{1-x} \mathrm{O}$ 基催化剂, 突破了“以 $\mathrm{Fe}_{3} \mathrm{O}_{4}$ 为母体的熔铁催化剂 具有最高活性”传统定论的束缚, 找到了提高熔铁催化 剂性能的突破口一维氏体催化剂体系. 它标志着 80 多年 来熔铁催化剂的研究取得了实质性的进展, 为熔铁催化 剂的发展注入了一线生机. $\mathrm{Fe}_{1-\mathrm{x}} \mathrm{O}$ 基氨合成催化剂是目 前世界上活性最高的熔融铁催化剂. 这一发现引起了国 内外同行学者的广泛关注和兴趣 ${ }^{[13,14,22,23]}$, 并已在工业 上得到广泛应用。

作者 ${ }^{[24]}$ 有幸从 20 世纪 60 年代开始目睹了我国合成 氨工业的建设和发展, 毕生致力于催化合成氨技术的研 发, 参加了从 $\mathrm{Fe}_{3} \mathrm{O}_{4}$ 基、含钴 $\mathrm{Fe}_{3} \mathrm{O}_{4}$ 基、 $\mathrm{Fe}_{1-x} \mathrm{O}$ 基到钉基催 化剂等各阶段催化剂的研究, 并努力做出贡献. 创立了 其中的 $\mathrm{Fe}_{1-x} \mathrm{O}$ 基催化剂, 与同事们一起开发成功A110-2, A301, ZA-5等系列新型工业催化剂, 成为我国近 30 年合 成氨工业主干催化剂之一。

\subsection{2. 钉基氨合成催化剂的发现}

国外对固定不变的 $\mathrm{Fe}_{3} \mathrm{O}_{4}$ 基催化剂已不期待有很大 的提高, 开始寻找替代铁催化剂的非铁贵金属催化剂. 40 多年前, Ozaki等 ${ }^{[25]}$ 在一篇综述文章中提出了氨合成 和分解中元素的催化效率与氮的化学吸附能相关联, 得 到一条能够定量描述金属元素在氨合成中的催化效率 的火山形曲线. 在这条曲线中, 钉、锇和铁在火山形的顶 端. 在工业条件下, 使用Ru和Os催化剂已经接近最佳点. 近百年的理论和实践研究结果都表明, Ru, Os和 $\mathrm{Fe}$ 在纯
金属中是最好的催化剂.

钓催化剂已有着较长的发展历史 ${ }^{[26]}$. 第一个有关 钉用于氨合成催化反应的研究报道是在 1917年, Mittasch等认为在合成氨过程中钉催化剂的活性不如铁催 化剂. 之后, 很长一段时间未见文献报道. 1969年, Tamaru等 ${ }^{[27]}$ 提出过渡金属电子授受型(EDA, electron donor-acceptor)氨合成催化体系, 碱金属钾或钠为电子 授予体, 过渡金属铁、钉、锇、钴等为电子接受体, 选择 具有电子传输能力的酞等、聚苯醌、石墨或石墨化活性 炭为载体, 在温和条件下具有较高的氨合成催化活性. 1972年, Ozaki课题组等 ${ }^{[28]}$ 发现, 钓为活性组分、金属钾 为促进剂、活性炭为载体的催化剂对氨合成有很高的活 性. 这一发现再次激发了人们研究钓催化剂的兴趣. 之 后, 日本、苏联、英国、美国、意大利等国的学者, 以及 我国浙江工业大学、福州大学、厦门大学、大连化物所 等单位 ${ }^{[29-32]}$ 将大量的精力投入到研制钓催化剂以期取 代传统的铁基催化剂上. 由英国石油公司(BP)负责开发 以钉的羰基化合物负载于含石墨炭载体上的 $\mathrm{Ru} / \mathrm{C}$ 催化 剂, 以Kellogg负责开发与其配套的氨合成工艺, 经过 10 年的共同努力, 于 1992 年开发成功适用 $\mathrm{Ru} / \mathrm{C}$ 催化剂的 KAAP(Kellogg Advanced Ammonia Process)新型氨合成 工艺流程, 并实现了工业应用 ${ }^{[33-35]}$.

钓催化剂虽然活性很高, 但存在 $\mathrm{H}_{2}$ 的强烈抑制作用, 而且以炭材料为载体的 $\mathrm{Ru}$ 催化剂在合成氨的条件下, 载 体碳在钓的作用下会发生甲烷化反应, 致使活性炭载体 的流失而影响催化剂的寿命. 这是钉催化剂的一个弱 点. 同时, 由于 $\mathrm{Ru}$ 和 $\mathrm{Os}$ 非常昂贵, 相对第三好的 $\mathrm{Fe}$ 催化 剂而言缺乏商业吸引力 ${ }^{[36]}$. Os和U在 20 世纪初就被 Haber的早期研究所淘汰. $\mathrm{Ru} / \mathrm{C}$ 催化剂在节能方面也没 有太大的优越性(表2). 从1992年至2010年, 仅有16家合 成氨装置采用钓催化剂. 因此, 可以说钓催化剂的理论 意义大于实用意义, 工业上仍有必要寻找比钉更廉价的 高效催化剂.

\subsection{3. 钴钼氮化物氨合成催化剂的发现}

Nörskov课题组等 ${ }^{[36]}$ 提出了一种周期表内插入法预 测合金催化剂的原理. 这种催化剂开发策略是通过简单 的物理原理得出, 其基本原理可以广泛应用. 根据这个 原理, 一个合理的设想是, 在A.Ozaki等得到的火山形曲 线中, 把这条曲线上与氮反应很活泼的与很不活泼的元 素形成合金来构造一个活性表面, 以达到最优化的性能. 结果发现, 钴钼氮化物催化剂的活性比Ru和Os更接近曲 线的顶点; 比各自组分有更好的氨合成活性, 在低 $\mathrm{NH}_{3}$ 
浓度下比 $\mathrm{Fe}$ 和 $\mathrm{Ru}$ 还要好 ${ }^{[37-41]}$. 非钉的钴钼氮化物催化 剂的发现被认为是到目前为止在氨合成催化剂的研究 中根据理论预测而合理发展的最新顶点 ${ }^{[42,43]}$.

G. Ertl ${ }^{[4]}$ 和Somorjai课题组 ${ }^{[45]}$ 的实验可以提高对氨 合成的认识, 并且允许对这个反应进行定量的理论描述 和预测. 首先在反应途径的基本知识和过渡态理论的基 础上, 能够得到元素在氨合成中催化效率的火山型曲线 的定量描述. 由此可以预测合金体系的催化效率 ${ }^{[36,46]}$. 在Co-Mo-N体系上得到的研究结果 ${ }^{[36,47]}$, 证实了理论和 经验在催化剂的选择上是同等有用的. 这一令人注目的 成功例子表明: 根据目标反应过程, 在纯理论基础上可 以设计一个催化剂体系 ${ }^{[36,48]}$. 因此, 非铁类和合金类催 化剂的发现将再次推动多相催化科学的发展.

这里值得关注的是, 氨合成催化剂的发现和发展在 催化剂的研究方法上给我们提供的启发. 在发明氨合成 催化剂时, Mittasch等采用的是大量试验的研究方法, 在 当时是一种完全新颖的方法. 这种方法如此有效, 以致 迄今基本上仍然沿用这种方法. 而钴钿氮化物催化剂的 发现给我们提供了另一种全新的研究方法, 即可以在纯 的理论基础上来设计催化剂, 包括周期表内插入法设计 催化剂. 随着催化科学理论知识和规律性认识的深入, 大量丰富的资料和经验的积累, 特别是随着计算机技术 的发展, 为从理论基础上并在“分子”水平上来设计催化 剂, 提供了可能. 近年来人们纷纷开发各种专家系统等 来辅助催化剂的设计 ${ }^{[49-52]}$.

\section{2. 熔铁催化剂的特征及其理论与实践的启示}

合成氨中的催化化学极具魅力, 吸引了众多化学家 的注意力和兴趣. 许多当代著名的物理化学家和催化科 学家, 如W. H. Nernst, W. Ostward, F. Haber, C. Bosch, M. I. Temkin, G. Ertl, P. Emmett, A. Nielsen, H. Topsøe, G. A. Samorjai, J. A. Dumesic, J. K. Norskov, M. Boudart 等都曾参与或涉及合成氨催化剂的研究 ${ }^{[53-58]}$, 出版了不 少专论 ${ }^{[24,59-62]}$. 这是因为熔铁催化剂具有某些特殊的性 能.

(1) 在20世纪化学工业的发展中, 催化合成氨技术 起着核心的作用 ${ }^{[63]}$. 这个工业的重要性与人们对氨合 成催化剂的重要科学价值和技术进步的理解具有浓厚 兴趣相关联. 通常, 与催化作用相关的新技术、新方法和 新理论的发展往往是从这个反应系统的研究开始, 或者 首先被应用于这个反应体系. 同样地, 在氨合成催化领 域得到的新发现往往被延伸到其它催化领域. 而精细的 表征技术、动力学分析、新理论模型的发展也极大地促
进了人们对氨合成催化剂基础的深入理解.

百年来, 虽然历经不断地改进, 但熔铁催化剂的本 质未变. 迄今为止, 所有对氨合成反应理论的研究都是 以这种催化剂为基础的. 例如, 在铁催化剂上完成的著 名的BET吸附理论; P. Emmett用选择性化学吸附测定催 化剂表面活性组分的方法; 建立在以氮对 $F e(111)$ 晶面 有选择性吸附现象为基础的工作, 奠定了 20 世纪 80 年代 逐步形成的金属簇催化理论; G. A. Somorjai的“具有最 大配位体的晶面具有最高催化活性”的重要假定以及结 构敏感反应概念; J. Horiuti的化学计量数的概念首先是 为了验证合成氨反应动力学机理而提出的, M. I. Temkin理论及其著名的合成氨反应动力学方程, 第一次成功 地而且至今仍然应用于工业反应器设计, 并奠定了多相 催化反应动力学基础. 这些理论和概念, 带动了一系列 基础理论的发展, 奠定了多相催化科学的基础. 氨合成 反应及其催化剂的发展史是多相催化学科发展史的缩 影.

Temkin的非均匀表面的催化反应动力学理论不仅 得到了铁催化剂上合成氨总包反应动力学数据的证实, 而且更重要的或许还是由这个理论导出一些非常有用 的普遍性结果. 例如, Temkin方程是在两步机理或者能 简化为两步机理的基础上推导得到的, 并且在催化动力 学研究中, 通常可以忽略催化剂表面的非均匀性, 把它 当作均匀表面来处理, 因此适用于任何一类催化反应. 其次, 对于多位吸附, 不同的催化剂活性具有巨大差别 源自于活性位的多重性的推理, 对于非均相催化反应的 结构敏感性的讨论是极其重要的. 第三, 在Temkin理论 的推导中引入了活性位分布函数的概念, 由此可导出许 多众所周知的吸附等温线, 如 Freundlich, Frumkin-Temkin表达式及其它公式以及Elovich方程式等吸 附速率定律. 由此推导得出最佳活性位或最佳催化剂应 该具有适中的亲和势数值, 即表面能量分布处于中央的 活性位. 这些结果可以看成是Sabatie最佳催化剂能够容 易形成足够稳定但又不太稳定的中间化合物原理的体 现并得到解释 ${ }^{[64]}$.

这些理论为催化研究提供了有价值的信息, 即为了 得到最佳催化剂, 必须改变亲和势的数值. 例如, 对于金 属催化剂可用如下3种方法: 首先, 通过改变暴露的晶面 或改变粒子的大小来改变表面结构, 在这两种情况下, 都包括改变具有不同配位数的原子在表面的相对分布 比例; 第二, 可通过形成合金(例如将铜加入到镍中)或 添加表面杂质(例如硫、碳、氧、氮)来改性金属催化剂 ${ }^{[9]}$; 
第三, 根据周期表改变催化剂中金属成分笁选最佳催化 剂, 例如钴钿氮化物催化剂的发现. 为了使这种方法比 较有意义, 必须假定反应机理不发生变化. 但是, 通常在 引进一种新催化剂并经过一些时间后, 其活性可提高到 一定水平, 进一步提高将变得十分困难. 要突破这一水 平, 似乎必须发现不同的化学反应步骤序列, 即要发现 另一种不同的反应机理.

实践表明, 没有别的反应象氨合成反应一样, 能够 把理论、模型催化剂和实验连接起来. 在低压得到的研 究结果能够被高压实验证实; 从超高真空得到的动力学 可以外推到工业条件; 在单晶上的研究结果可以应用理 论来描述 ${ }^{[44,65]}$. 这个状态不但对铁催化剂适用, 对钓催 化剂和 $\mathrm{Co}_{3} \mathrm{Mo}_{3} \mathrm{~N}$ 催化剂都适用. 而且, 了解这些催化剂 知识所需的时间越来越短, 尽管催化剂在结构和化学组 成上变得更加复杂 ${ }^{[13]}$. 因此, 催化合成氨反应仍然是多 相催化理论研究的一个理想的模型体系.

(2) 氨合成反应是最简单的化学反应之一, 是一个 没有副产物、没有选择性的原子利用率为 $100 \%$ 的绿色 化学反应, 特别是通常产品氨与排放的 $\mathrm{CO}_{2}$ 联产尿素或 碳酸氢铵时, 更是一个没有排放的清洁生产工艺, 是至 今工业上少有的 $\mathrm{CO}_{2}$ 捕集、封存和利用的成熟技术之 - ${ }^{[66]}$. 在工业上, 实现该反应的合成氨过程却是化学工 业中最复杂、最典型的化工过程之一; 在理论上, 该反应 是一个在常温常压下能够实现而在实践上却是一个非 常困难、必须在高温高压下实现的反应. 因此, 理解氨合 成催化反应机理并转换成完美技术成为催化领域发展 的基本标准.

（3）现代工业铁催化剂是一种纳米结构的亚稳态物 质, 它是以氧化物为前驱体在非常复杂的过程中合成 的 ${ }^{[67,68]}$. 这个亚稳态也是在活化和氧化活化材料时产生 过热应力的敏感性的原因. 制备纳米结构的路线是可以 选择的, 例如 $\mathrm{Fe}_{3} \mathrm{O}_{4} \rightarrow \mathrm{Fe}_{1-x} \mathrm{O}^{[69-72]}$, 并且看起来似乎非常 简单的铁催化剂的结构却是非常复杂的. 一个令人吃惊 的例子是仅仅使用不同的催化剂前驱体能引起金属表 面纳米结构的巨大改变. 新发明的维氏体基催化剂已经 被证实比磁铁矿基催化剂具有更高的活性 ${ }^{[23]}$. 定量分 析研究表明, 在铁催化剂中, 只有不到 $1 \%$ 铁表面参与了 氮的活化, 其余 $99 \%$ 的铁只是起着一种载体的作用 ${ }^{[73]}$. 如果能够有更多的铁暴露在表面, 将可以大大提高催化 剂的活性. 有人则以铁催化剂为载体, 在其表面涂附上 纳米铁, 制备出涂附纳米铁的铁催化剂.

(4) 氨合成催化剂是所有工业催化剂中最稳定的.
上述这种纳米结构的亚稳态物质在多孔和苛刻的反应 条件下使用 15 年以上, 其结构几乎不变. 对此, 曾进行了 大量的研究和表征, 提出了许多模型来解释这种稳定的 活性表面结构及其形成机理 ${ }^{[10,55,74-79]}$.

(5) 高度与工业关联的催化氨合成反应仍然是一个 制造新生命的关键反应, 一个有助于催化剂的基本理解, 在科学和文化上有着相当重要性的原型反应 ${ }^{[80]}$. 尤其 是基础知识的进步对其它领域的催化剂研究有较大的 影响.

例如, 在合成氨的生产过程中, 从制气、净化到合成, 主要的化学反应都是通过多相催化过程完成的, 催化剂 起着极为重要的作用. 其中以天然气或石脑油为原料的 蒸气转化法制氨过程中使用了9种催化剂, 包括烃类加 氢转化催化剂、一段/二段蒸气转化催化剂、高温/低温 变换催化剂、甲烷化催化剂、氨合成催化剂、 $\mathrm{CO}$ 选择 性氧化催化剂等; 以渣油为原料的部分氧化法和煤加压 气化制氨工艺还使用耐硫变换催化剂、Claus硫回收催化 剂、 $\mathrm{CO}_{2}$ 脱氢催化剂、各种脱毒催化剂、分子篮干燥剂 以及工艺过程制氮催化剂等 ${ }^{[81]}$. 无论何种制氨工艺, 变 换催化剂和氨合成催化剂都是不可缺少的, 它们是合成 氨工业的核心催化剂.

这十几种催化剂, 大多数是其它化工过程, 例如煤 化工、石油化工、天然气化工、生物化工、能源化工、 炼油工业以及环境保护等领域的基本催化剂, 例如加氢 转化脱硫催化剂、变换催化剂等是这些工业不可或缺的 催化剂. 此外, 合成氨工业还蕴含着一系列高新技术和 战略性新兴产业中需要解决的系列共性-关键技术. 而 催化合成氨过程本身还蕴含着巨大的节能潜力, 人们还 将继续不断地改进上述各种催化剂. 因此, 合成氨催化 剂的发展必将带动一系列其它催化剂的发展. 了解和熟 悉氨合成催化剂及合成氨工艺流程及其成熟技术和实 践经验, 对于了解现代化工、能源、材料、环保领域一 系列共性、关键技术, 尤其是对于传统工业的节能减排、 新型煤化工、制氢和清洁能源等战略性新兴产业, 具有 强烈的启迪和借鉴作用 ${ }^{[82]}$.

\section{3. 氨合成催化剂面临的挑战}

进入 21 世纪, 有人把合成氨称之为是“夕阳工业”. 国外也有人哀叹: 固氮化学的前景黯淡 ${ }^{[83]}$. 对此, 德国 Schlög ${ }^{[13]}$ 发表了题为“Catalytic Synthesis of AmmoniaA Never-Ending Story?”的短评, 指出催化合成氨的故事 永远不会结束. 
（1）氮的循环是自然界中维持地球上生命的最重要 的循环之一, 氨也是现代社会运转必不可少的原料, 它 赋予合成氨工业旺盛的生命力. 这些材料的合成都需要 合成氨作为活化态的氮. 催化合成氨是自然界中氮循环 的重要一环, 是生物(包括人类)所需要的活化态氮的重 要补充, 而且是目前唯一具有工业规模的获取活化态氮 的方法. 目前除了催化合成氨以外, 期望通过其他途径 获得活化态氮都还只能是科学研究的课题. 虽然生产合 成氨需要使用各种含碳燃料获得 $\mathrm{H}_{2}$ 气, 然而无论能源供 应将会如何紧缺, 环境控制如何日益严格, 粮食的刚性 需求决定了合成氨工业必须依靠科技进步来面对这一 严峻形势而继续发展, 并推动着氨合成催化剂的不断改 进与创新, 以满足人类生存和社会发展的需要. 因此, 合 成氨工业是一个具有旺盛生命力的不可替代的传统工 业.

(2) 合成氨生产的原料和燃料都是能源. 当今全球 关注的能源问题又摆在合成氨工业的面前, $\mathrm{CO}_{2}$ 的排放 也将受到严格限制, 节能减排始终是合成氨工业面临的 重大课题. 现代以天然气为原料的先进氨厂的综合能耗 已达到 $27.5 \mathrm{GJ} / \mathrm{t}$ 左右, 过程的总热效率达到 $70 \%$ 以上 ${ }^{[84]}$. 商业铁催化剂和钉催化剂能够达到上述效益 ${ }^{[85,86]}$. 催化 剂中的任何一个进步都能够提高热力学效益和降低产 物的价格 ${ }^{[87]}$. 应该强调的是, 从表面上看, 能量损耗主 要在于转化工序, 而实质上应在于合成工序. 因为占能 耗 $30 \%$ 左右的动力消耗主要为合成服务 ${ }^{[88]}$. 合成氨的高 压主要是为了跨越合成氨反应的活化能势垒, 而活化能 势垒高低决定于催化剂的活性. 为了跨越这一反应障 碍, 消耗了占吨氨总能耗约 $30 \%$ 的能量, 付出了多么高 昂的代价! 因此, 开发新型低压合成氨催化剂意义非同 小可.

(3) Haber-Bosch固氮过程中没有涉及在催化反应中 使用别种形式的能量, 如电能、光能等, 以及催化剂在不 同形式的能量相互转化中的作用. 在现实生产实践中, 别种形式的能量转化, 如由化学能、太阳能、风能、水 能和核能转化为电能; 电能、光能转化成化学能等都格 外引人注意.

在以矿石燃料的热能作为唯一驱动力的 Haber-Bosch固氮过程中, 既使余热回收及梯级利用最先 进的氨厂 (总能效高达 $74 \%$ 以上), 不仅还有 $20 \%$ 以上的 节能潜力, 而且至少消耗 $27.5 \mathrm{GJ} / \mathrm{t}$ 以上热能的燃料. 既 使在极限状态(总能效 $100 \%$ )下, 也必须消耗 $20.13 \mathrm{GJ} / \mathrm{t}$ 以 上热能的矿石燃料.
因此, 将电能、光能、辐射能引入合成氨过程辅助 氮分子的活化或改变反应途径, 并研究催化剂在不同形 式的能量相互转化中的作用具有现实和理论意义.

(4) 众所周知, 催化化学研究的重点和难点是自然 界中最稳定的几种小分子 $\left(\mathrm{CO}_{2}, \mathrm{H}_{2} \mathrm{O}, \mathrm{CO}, \mathrm{CH}_{4}, \mathrm{H}_{2}, \mathrm{~N}_{2}\right.$, $\mathrm{O}_{2}$ ). 氮分子是最难活化的单质, $\mathrm{N} \equiv \mathrm{N}$ 三键离解能高达 $942 \mathrm{~kJ} / \mathrm{mol}$, 断裂该键需要极高的能量. 如何活化氮分子 是固氮所面临的关键理论问题. 氮分子的活化也成为化 学和催化领域研究的原型分子之一, 具有典型的代表性 意义.

(5) 氨合成反应在 $25^{\circ} \mathrm{C}$ 的标准平衡常数高达 $6.8 \times$ $10^{5}$, 理论上预测在室温和常压下氨合成是可能的,但反 应速率几乎无法察觉. 因此, 这是一个新的挑战. 由于 固氮对人类的生存和发展具有重要意义, 因此实现常温 常压合成氨一直是人类不懈追求的目标.

综上所述, 降低现有合成氨技术的能耗, 寻找新的 合成氨的方法和途径, 探索常温常压合成氨的可能性等, 是催化合成氨技术面临的新挑战.

实现常温常压合成氨的关键是氮分子的活化和能 量的提供形式与途径.

\section{1. 氮分子的活化}

将空气中游离态的氮气转化为含氮化合物的过程 称为固氮, 主要包括化学固氮和生物固氮. 用化学方法 活化氮分子主要有 3 条途径.

（1）还原法, 用还原剂给予 $\mathrm{N}_{2}$ 电子. 催化合成氨属 于还原法. (2) 氧化法, 用氧化剂夺走氮分子中的电子. 由于 $\mathrm{N}_{2}$ 的第一电离能很高, 目前尚未找到这样强的合适 的可形成催化循环的氧化剂. (3) 物理-化学法(激活法), 用强烈的条件如高压放电、等离子体等物理手段, 把 $\mathrm{N}_{2}$ 从基态激发到高能状态, 甚至把它拆开, 使之成为氮原 子或氮离子, 然后与别的物质起反应. 例如: 早期的电 弧法和氧胺化钙法. 巨大的能量消耗大大限制了这两种 方法的工业应用. 近年来, 关于等离子体合成氨 ${ }^{[89-92]}$, 磁 诱导法合成氨 ${ }^{[93]}$ 等的研究方面也较活跃, 但目前仍处于 探索阶段.

因此, 催化还原法占据无可争议的主导地位, 也是 目前唯一具有工业规模的化学固氮方法. 由于人们对此 过程进行了长期的研究和探索, 目前在钉和 $\mathrm{Fe}_{1-x} \mathrm{O}$ 基铁 催化剂作用下, 起始活性温度已可以降低到 $200{ }^{\circ} \mathrm{C}$ 左 右 ${ }^{[94]}$. 例如, ZA-5 在某企业合成高纯氨制备工艺中, 进 口温度 $215^{\circ} \mathrm{C}$, 出口温度 $363^{\circ} \mathrm{C}$, 压力 $8 \mathrm{MPa}$, 氨净值高于 $10 \%$, 已经可以满足工程上经济性对氨净值的要求, 关 
键在于相应低压工艺技术的开发. 但可以预见, 进一步 开发更低温度和压力下高活性催化剂仍有相当的难度.

历时长达一个世纪的催化合成氨的研究, 可以说就 是 $\mathrm{N}_{2}$ 的活化方式及其本质的研究历程. 各种现代精密物 理-化学仪器都曾用于 $\mathrm{N}_{2}$ 的活化及其机理的研究. 然而, 迄今在铁催化剂上氮的活化究竟属于解离吸附还是分 子吸附仍时有争议. 绝大多实验事实是支持 $\mathrm{N}_{2}$ 解离吸附 的 ${ }^{[70,95-97]}$. 例如对于在Fe催化剂上, G. Ertl ${ }^{[98]}$ 提出了一 个基于 $\mathrm{N}_{2}$ 解离吸附的合成氨催化反应机理及其热化学 动力学位能图(图1). 这是2007年G. Ert1获诺贝尔化学奖 的代表性成就之一 ${ }^{[99]}$. M. Boudart ${ }^{[80]}$ 认为图1具有很大 的指导意义, 要真正清楚地了解催化反应机理, 就要象 合成氨催化反应那样, 能够提供如图 1 那样的热化学动 力学剖面图. 理论工作者正在设法去计算催化循环中基 元步骤所缺少的许多能量值 ${ }^{[100]}$.

也有许多实验事实是支持 $\mathrm{N}_{2}$ 分子吸附的 ${ }^{[65,101-106]}$. 例如, 廖代伟等 ${ }^{[107,108]}$ 用反应能量学的多相催化反应分 子设计和键级守恒莫尔势函数法(BOC-MP) 以及気反同 位素效应 ${ }^{[109]}$ 研究了铁和钓催化剂表面氨合成反应的缔 合式和解离式两种机理, 计算表明缔合式机理速控步骤 的活化能垒低于解离式速控步骤的活化能垒, 但反应的 活化能垒又明显低于缔合式途径速控步骤的活化能 垒. 由此可推断, 在铁催化剂表面存在着两种氨合成竞 争反应途径.

在铁催化剂上合成氨中, 从示踪物的转移测得的总 包反应和速率决定步骤的化学计算数 $\sigma_{\mathrm{rds}}$ 可以等于 1 或 2 , 如图2所示. 这两种数值在实验工作中都已有报道. Horiuti等 ${ }^{[110,111]}$ 发现在接近平衡时, $\sigma_{\mathrm{rds}}=2$; 而Tanaka ${ }^{[112]}$ 发 现在远离平衡时, 合成反应的 $\sigma_{\mathrm{rds}}=2$, 而分解反应的 $\sigma_{\mathrm{rds}}$ $=1 . \sigma_{\mathrm{rds}}=2$ 适合于图 $2(\mathrm{a})$ 步骤 2 为速率决定步骤, 但是很 多证据指出氮的吸附是速率决定步骤, 这时 $\sigma_{\mathrm{rds}}=1$, 但 $\sigma_{\mathrm{rds}}=1$ 却不能确定吸附是解离的还是不解离的. 可以想 象的是存在如图2(b)所示的反应序列, 其中最先的两步 被认为是固氮酶通过它们实现固氮. 倘若如此, $\sigma_{\mathrm{rds}}$ 仍等 于1. 然而, 在铁上氮的解离化学吸附的证据现在是占压 倒优势的. 在铁上解离和在固氮酶上不解离这两种反应 序列正好是高温下工业催化作用和低温下酶催化作用 各自的特征. 因此, 为了从本质上改善当前合成氨铁催 化剂的活性, 可能必须根本改变在铁催化剂上反应序列 中各步的性质 ${ }^{[10]}$.

因此, 图1和图2所示关于 $\mathrm{N}_{2}$ 的活化形式、氨合成反 应的基本步骤、真实结构, 这些问题还蕴涵着丰富的科
学暗示, 新的高效的氮分子活化方法还有待探索 ${ }^{[57]}$. 氮 分子活化在化学和催化科学研究中依然是一个挑战, 依 然具有重要的理论和现实意义.

\section{2. 催化合成氨在理论上的新挑战}

液氨的热值为 $21.29 \mathrm{GJ} / \mathrm{t}$, 有效能 (exergy) 为 20.13 $\mathrm{GJ} / \mathrm{t}$, 而实际能耗要高得多. 因此无论用什么原料和工 艺合成氨, 需要提供的有效能不可能少于 $20.13 \mathrm{GJ} / \mathrm{t}$. 以 水和空气为原料、矿石燃料的热能为驱动力的HaberBosch固氮过程, 由于原料提供的有效能值多于产品的 有效能值, 因而该过程的理想功为正, 每生产 $1 \mathrm{t} 25^{\circ} \mathrm{C}$ 的 饱和液氨, 理论上都是可以对外作功的过程(表3). 例如 以纯 $\mathrm{H}_{2}$ 和纯 $\mathrm{N}_{2}$ 为原料的制氨过程可以对外提供 $0.63 \mathrm{GJ} / \mathrm{t}$ 的外功, 但直接以水和空气为原料的固氮过程,必须消耗 外功, 其过程理论能耗达 $20.31 \mathrm{GJ} / \mathrm{t}$. 由两者的比较可知, 固氮过程中能量主要损耗在把空气中的氮和水中的氢 取出来的过程. 因此, 如果能通过其它形式的能量如电 能、光能等, 把水中的氢取出来, 就可以改变反应途径. 虽然仍然至少要消耗 $20.31 \mathrm{GJ} / \mathrm{t}$ 以上的电功, 但电能可以 采用可再生能源, 如太阳能、风能、水能或核能等转化 而来. 由此固氮过程就可以不使用矿石燃料, 那将是合 成氨工业的彻底革命!

因此, 将电能、光能等引入固氮过程, 改变反应途径 或仿生合成氨是催化科学工作者面临的重大挑战之一, 具有重大的理论和现实意义.

\subsection{1. 电催化合成氨催化剂研究}

电催化合成氨可使热力学非自发反应 $\mathrm{N}_{2}+3 \mathrm{H}_{2} \mathrm{O}=$ $2 \mathrm{NH}_{3}+1.5 \mathrm{O}_{2}\left(K_{298}=10^{-120}\right)$ 在电能的推动下发生, 从而 拓展氨合成方式的研究领域; 也可使受平衡限制的合成 氨反应不受或少受热力学平衡的限制. 因此, 将电能引 入合成氨过程辅助氮分子的活化或改变反应途径一直 是备受关注的研究领域之一. 电化学方法与现有合成方 法的效率相似, 是一种可取的常温常压合成氨方法 ${ }^{[114]}$. 例如, 在高温 $\left(570{ }^{\circ} \mathrm{C}\right)$ 常压下进行的电化学方法合成氨, 氢气的转化率可接近 $100 \%$. 因此, 近年来电化学常温常 压合成氨的研究也相当活跃 ${ }^{[115-118]}$.

曾研究过的主要电催化剂包括负载铁酞菁催化剂 的气体扩散电极, 陶瓷固体电解质以及熔盐 $(\mathrm{LiCl} / \mathrm{KCl} / \mathrm{CsCl})$ 等. 采用室温下具有高质子导电性的固 体电解质, 提高电流效率和电极稳定性是电化学合成氨 未来研究的重要方向 ${ }^{[87,119,120]}$.

电流效率过低是影响电化学合成氨效率和产品成 本的关键. 随着电化学合成氨的深入研究, 如果能够大 
幅度提高电流效率和转化率, 使得电化学合成氨的成本 主要集中到单纯的电能消耗上, 则电化学合成氨在电能 充足、或可有效地将太阳能、风能和水能转化为电能的 偏远地区有望占有一席之地. 特别是在未来当由于能源 危机导致石油、天然气、煤炭等合成氨原料价格大幅度 上扬致使合成氨成本成倍增长时, 电化学合成氨将不失 为一种有益的选择. 因此, 电化学合成氨研究依然具有 潜在的应用前景 ${ }^{[115]}$.

\subsection{2. 光催化合成氨催化剂的研究}

人们最为熟悉的光催化反应是自然界的光合作用: $\mathrm{CO}_{2}+\mathrm{H}_{2} \mathrm{O} \rightarrow \mathrm{CH}_{2} \mathrm{O}+\mathrm{O}_{2}$. 绿色植物通过叶绿素 (光敏 剂)吸收阳光, 通过植物体中的酶, 由 $\mathrm{CO}_{2}$ 和 $\mathrm{H}_{2} \mathrm{O}$ 光合成 碳水化合物, 放出 $\mathrm{O}_{2}$. 光合作用是将光能转化为化学能 的最重要途径. 复杂的光合作用进程中最关键的一步是 光合作用反应中心里的物质接受光能释放出电荷, 并将 电子转送到细胞中引起化学合成反应, 从而将光能储存 起来 ${ }^{[121]}$.

在常温常压下以水为氢源, 以太阳能为能源, 用光 催化的办法使空气中的氮直接转化为氨的反应: $\mathrm{N}_{2}+$ $3 \mathrm{H}_{2} \mathrm{O} \rightarrow 2 \mathrm{NH}_{3}+1.5 \mathrm{O}_{2}$, 则需要解决太阳能的输入方式 和采用光催化剂.

这两个反应相似, 都是热力学非自发反应, 且 $\mathrm{N}_{2}$ 比 $\mathrm{CO}_{2}$ 更难活化, 但在光催化理论上是可以实现的. 无论 是自然界中的 $\mathrm{CO}_{2}$ 还原反应还是人工的水还原 $\left(\right.$ 产 $\left.\mathrm{H}_{2}\right)$ 和 氧化 $\left(\right.$ 产 $\left.\mathrm{O}_{2}\right)$ 反应, 都是一个相当复杂的催化过程, 通常是 通过多电子途径发生、由若干个基元反应组合而成的. 1988 年诺贝尔化学奖共同获得者Deisenhofer等 ${ }^{[122]}$ 和 Michel等 ${ }^{123]}$ 通过理论计算, 认为非对称核因素(nuelear Frank-condon factors)与电子偶合的共同效应极可能是 单向电子传递的主要原因. 光合作用反应机理及其中心 结构的研究结果将为光催化合成氨提供启示.

光催化研究已有 50 多年历史 ${ }^{[24]}$. 所使用的光催化 剂大多为具有半导体特性的材料, 例如不同金属掺杂的 $\mathrm{TiO}_{2}$ 系列和 $\mathrm{WO}_{3}$ 系列 ${ }^{[125]}$, 以及 $\mathrm{CdS} / \mathrm{GaP}-\mathrm{Pt}, \alpha-\mathrm{Fe}_{2} \mathrm{O}_{3}-$ $\mathrm{Nd}_{2} \mathrm{O}_{3}$ 等催化剂 ${ }^{[126-132]}$. 目前人们正在不断地研制更有 效的催化剂 ${ }^{[133-135]}$, 提出常温常压合成氨的新方法. 这 说明人们正在向这个长期的奋斗目标探索.

\subsection{3. 化学模拟固氮酶仿生合成氨的研究}

在自然界, 有一种固氮微生物, 它们体内含有一种 具有特殊本领的催化剂一固氮酶, 它能在常温常压条件 下将空气中的氮直接还原为氨. 其固氮能力比 Haber-Bosch化学固氮过程高出成千倍. 据估计, 当今由
生物固定的氮已达 $0.2 \mathrm{Gt}$, 占地表化合态氮的 $48 \%$ 左右 (其余 $52 \%$ 由合成氨提供). 生物固氮, 无论从其所需的条 件, 还是固氮能力, 都大大超过了化学固氮. 生物固氮可 分为生物固氮菌固氮法和仿生化学固氮法.

仿生化学固氮是用化学的方法, 模拟生物体内固氮 酶的功能, 制备优良的化学催化剂, 实现常温常压合成 氨. 这是催化科学工作者面临的一项挑战. 研究生物固 氮机理, 无论是生产上还是理论上都有重大的意义. 它 可以为化学模拟生物固氮提供重要的依据. 固氮微生物 要实现固氮, 必须具备三个基本条件 ${ }^{[136]}$ : (1) 固氮酶; (2)

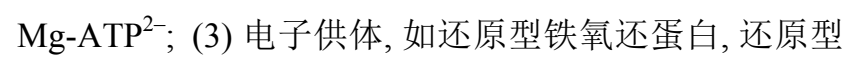
黄素氧还蛋白, 或人为的 $\mathrm{Na}_{2} \mathrm{~S}_{2} \mathrm{O}_{4}$, 为 $\mathrm{N}_{2}$ 还原提供电子. 20世纪70-80年代, 我国著名科学家唐謷庆、卢嘉锡、蔡 启瑞为首的一批科技工作者深入开展了生物固氮酶及 其化学模拟研究工作 ${ }^{[137]}$, 并提出了固氮酶活性中心模 型 ${ }^{[138]}$. 经过世界各国科学家不断努力, 发展了化学模拟 固氮酶, 并创立了固氮分子遗传学方法, 使生物固氮研 究取得了重大进展, 特别是自美国学者Rees 等 ${ }^{[139-143]}$ 阐 明了固氮酶的活性中心原子簇及其周围多肽分子的三 维结构后, 化学模拟生物固氮的研究再次掀起热 潮 ${ }^{[144-151]}$. 同时, 选择性酶的发展将是有机化学和生物 技术丰富的催化剂来源 ${ }^{[152]}$. 虽然, 迄今未能取得令人满 意的实用性成果, 但是人们对于生物固氮及其仿生氨合 成的研究和探索不会停止.

此外, 生物固氮菌固氮法中, 主要是通过生物工程, 在非豆科作物接种根瘤菌, 将固氮基因和其它相关基因 或固氮生物引人非豆科作物, 实行自我供氮 ${ }^{[153]}$. 随着转 基因育种技术的发展, 实现非豆科作物接种根瘤菌自我 供氮, 并大量种植豆科等油料作物(含氮 $7 \%-8 \%$ ), 充分 发挥油料作物根瘤菌共生固氮作用, 减少化学氮肥用量 是解决农业生产中大量施用化肥的负面影响的途径之 -[137].

\section{4. 结束语}

合成氨中的催化化学极具魅力, 熔铁催化剂所具有 的某些特殊性能是其它许多催化剂难以比拟的. 高度与 工业关联的催化氨合成反应仍然是一个制造新生命的 关键反应, 一个有助于催化剂的基本理解, 在科学和文 化上有着相当重要性的原型反应, 理解氨合成催化反应 机理并转换成完美技术成为催化领域发展的基本标准, 尤其是基础知识的进步对其它领域的催化剂研究有较 大的影响, 它仍然是多相催化理论研究的一个理想的模 
型体系.

催化合成氨技术在 20 世纪化学工业的发展中, 起着 核心的作用. 人类需要食物, 食物需要氮素, 催化合成氨 的故事永远不会结束. 氨也是现代社会运转必不可少的 原料, 它赋予合成氨工业旺盛的生命力, 并将继续推动 着氨合成催化剂的不断改进与创新. 在 21 世纪, 催化合
成氨技术将面临新的理论和实践的挑战. 降低现有催化 合成氨技术的能耗, 将电能、光能引入合成氨过程及化 学模拟固氮酶辅助氮分子的活化或改变反应途径, 寻找 新的合成氨的方法和途径, 探索常温常压电化学催化、 光催化合成氨、化学模拟生物固氮的研究, 是备受关注 的研究领域. 